
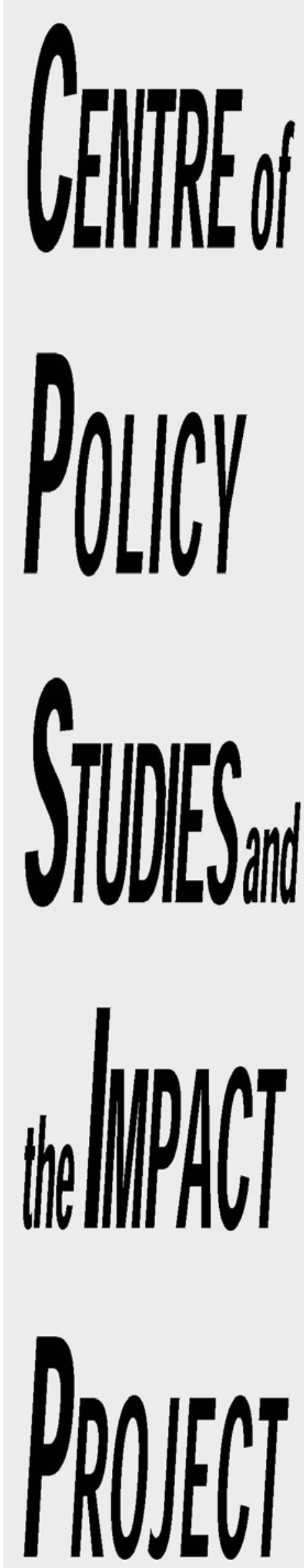

Eleventh Floor, Menzies Building Monash University, Wellington Road CLAYTON Vic 3800 AUSTRALIA

Telephone:

(03) 9905 2398, (03) 99055112

Fax:

(03) 99052426

e-mail:

Internet home page: from overseas:

61399052398 or

61399055112

61399052426 impact@buseco.monash.edu.au http//www.monash.edu.au/policy/

\title{
A General Framework for Measuring VAT Compliance Rates
}

by

\author{
J.A. GIESECKE \\ Centre of Policy Studies \\ Monash University
}

AND

TRAN HOANG NHI

Centre of Policy Studies

Monash University

General Paper No. G-206 August 2010 



\section{A general framework for measuring VAT compliance rates}

\section{J.A Giesecke ${ }^{\mathrm{a}}$ and Tran Hoang Nhi}

1. INTRODUCTION 3

2. EXISTING MEASURES OF VAT COMPLIANCE 4

3. A GENERAL FRAMEWORK FOR MEASURING VAT COMPLIANCE RATES 7

4. PARAMETERISING THE VAT MODEL TO VIETNAM'S VAT SYSTEM 17

$\begin{array}{lll}4.1 & \text { Legal VAT rates } & 19\end{array}$

$\begin{array}{lll}4.2 & \text { Legal exemption rates } & 20\end{array}$

$\begin{array}{lll}4.3 & \text { Non-registration rates } & 21\end{array}$

4.4 Refund rates for inputs into production and investment 23

4.5 Theoretical base and theoretical VAT liabilities 24

5. FROM CE TO CR: DECOMPOSING THE DIFFERENCE BETWEEN VIETNAM'S INDICES OF COLLECTION EFFICIENCY AND COMPLIANCE RATE

5.1 Legal rates 28

$\begin{array}{llr}5.2 & \text { Legal exemptions } & 29\end{array}$

$\begin{array}{lll}5.3 & \text { Industry non-registration rates } & 30\end{array}$

$\begin{array}{lll}5.4 & \text { Non-refundability of some investment } 31\end{array}$

5.5 VAT on domestic non-resident purchases 32

6. CONCLUDING REMARKS 32

Figure 1. Equations of the VAT model $\quad 35$

Figure 2. Variables and parameters of the model, in alphabetical order 39

Table 1. Summary measures of VAT rates and bases in Vietnam, 2005

Table 2. Commodity composition of VAT bases (VBASE), aggregated across commodities and users (VND tr.). $\quad 42$

Table 3. Decomposition of the VRR -CR gap for Vietnam 43

$\begin{array}{ll}\text { REFERENCES } & 44\end{array}$ 


\title{
A general framework for measuring VAT compliance rates
}

\author{
J.A Giesecke ${ }^{\mathrm{a}}$ and Tran Hoang Nhi \\ Centre of Policy Studies, Monash University
}

Summary measures of VAT compliance rates are valuable for identifying problem areas in VAT implementation. They are also essential for meaningful cross-country and cross-time comparisons of VAT compliance. We present a comprehensive and general framework for calculating VAT compliance rates at both the economy-wide and detailed sectoral levels. Unlike existing measures of VAT compliance, our framework isolates a compliance measure from the effects on VAT receipts of detailed features of VAT systems as actually implemented by tax authorities. These features include multiple VAT rates, exemptions, registration rates, refund limitations, informal activity, taxation of domestic non-residents, and undeclared imports. We implement our comprehensive VAT compliance measure for Vietnam, a country with a complex VAT system. Our estimate of Vietnam's VAT compliance rate is about eleven percentage points higher than that calculated by the most popular measure of compliance, collection efficiency (CE). Our method facilitates decomposition of the difference between CE and our VAT compliance measure into the individual contributions of statutory and structural features of Vietnam's VAT regime.

Key words: VAT, collection efficiency, revenue ratio, compliance rate.

JEL: H25, H26, C68

${ }^{a}$ Corresponding author. E-mail: James.Giesecke@monash.edu. 


\section{INTRODUCTION}

The value-added tax (VAT) has become the most common general consumption tax in the world. ${ }^{1}$ The widespread use of the VAT is due in part to its perceived efficiency and effectiveness in raising tax revenue compared with other indirect taxes. $^{2}$ In the period 1998-2000, the average share of VAT revenue in total tax collected in countries with a VAT was over $20 \% .{ }^{3}$ However, like other taxes, the VAT is vulnerable to tax evasion, tax fraud and poor enforcement. Given the VAT's revenue raising importance, there have been many time series and cross-country studies investigating the effectiveness of VAT compliance and enforcement. The most popular measure of such effectiveness is the collection efficiency (CE) index. CE is defined as the ratio of actual VAT revenue to potential VAT revenue with full compliance. Most studies calculate potential VAT revenue crudely, multiplying a single VAT rate by the value of final consumption. In doing this, most researchers acknowledge that this crude measure ignores the detailed features of VAT systems as actually implemented by tax authorities - namely, differential VAT rates, VAT exemptions, differential registration rates, VAT refund on investment good purchases, and informal imports. However, use of the CE index in policy debate is not always as careful in qualifying the effects of these omissions. Moreover, in calculating CE indices that do not take into account the details of real-world VAT systems, VAT researchers risk seeing both their CE measures misinterpreted, and policy makers misinformed. In this paper we propose a new framework to calculate a

\footnotetext{
${ }^{1}$ By mid 2006 there were around 140 countries with a VAT (Bird and Gendron, 2007).

${ }^{2}$ See, for example, Cnossen (1990) and OECD (2008).

3 Bird and Gendron, 2007, p. 231.
} 
VAT compliance and enforcement index that takes account of the aforementioned features of real-world VAT systems.

The paper is structured as follows. In Section 2 we review existing measures of VAT compliance and the use of these measures in VAT research. Section 3 presents a comprehensive framework for modelling and calculating VAT compliance rates. In Section 4 we apply the framework to a complex real-world VAT system, that of Vietnam. Using the new framework, we calculate a measure of Vietnam's compliance rate and explore the specific influences on this measure of Vietnam's VAT system and economic structure. Section 5 concludes the paper.

\section{EXISTING MEASURES OF VAT COMPLIANCE}

Two measures of VAT revenue collection efficacy most commonly used by analysts undertaking cross-country and cross-time studies are VAT productivity (VP) and VAT collection efficiency (CE). VAT productivity is the ratio of VAT revenue to the product of the standard VAT rate and GDP. VAT collection efficiency is the ratio of VAT revenue to the product of the standard VAT rate and final consumption. These measures have been used in many studies to investigate compliance and enforcement issues. They have been used as instruments for: (i) understanding the cross-country determinants of VAT compliance (Aizenman and Jinjarak, 2008; De Mello, 2009; Gebauer et al., 2007); (ii) comparing VAT compliance across countries (Jack 1996, Bird and Gendron 2007, OECD 2008); (iii) comparing country-specific VAT compliance over time (Jack,1996; Gebauer et al., 2007; Hybka, 2009); (iv) 
determining the optimum VAT rate (Matthews, 2003); and (v) evaluating the effect of VAT reform models on VAT evasion (Gebauer et al., 2007). ${ }^{4}$

In using the VP and CE measures to investigate VAT characteristics and compliance, deviations from one in these measures are often interpreted as a measure of non-compliance due to tax evasion, tax fraud and administrative inefficiency or laxity $^{5}$. At the same time, most authors acknowledge that the deviations are likely to be due in part to limitations in the indices themselves, rather than variations in the particular VAT feature for which the index is being used as an instrument.

The VAT compliance literature identifies a number of limitations to the VP and CE measures. One limitation, easily corrected, is that the VP and CE indices do not exclude the VAT itself from their final consumption base. OECD (2008, pp. 6670) defines a modified version of the CE, which it calls the VAT Revenue Ratio (VRR). VRR is calculated using the pre-VAT value of the consumption base. An obvious shortcoming of all three measures (CE, VP and VRR) is that in calculating potential revenue, they use only one standard VAT rate. This is despite many countries having multiple rates, and with these rates often varying considerably. ${ }^{6}$

\footnotetext{
4 Aizenman and Jinjarak (2008) use the ratios as instruments for understanding how political and structural factors affect compliance and enforcement rates across countries. They found that the CE index is positively correlated to the urbanised share of the population, real GDP per capita, trade openness, political stability and political participation. It is negatively correlated to GDP share of agriculture. De Mello (2009) uses the CE index as a measure of tax compliance in a model of a tax avoidance game between taxpayers and the tax authority. Matthews (2003) uses a ratio similar to the $\mathrm{VP}$ as a measure of compliance in his estimate of the revenue maximising rate of VAT in the European Union. Gebauer et al. (2007) evaluate the effect of VAT reform models on VAT evasion in the EU in general and in Germany in particular. Hybka (2009) estimates and explains collection efficiency in Poland over time.

${ }^{5}$ See, for example, Aizenman and Jinjarak (2008); De Mello (2009) and Gebauer et al. (2007).

${ }^{6}$ Among 142 countries listed as having a VAT in Bird and Gendron (2007, pp. 223-226), 76 countries have one rate, 32 countries have two rates, and 25 countries have 3 rates. The remaining countries have even more rates. An extreme example is Brazil, where the standard rate is 20.5 per cent, but there exist more than twenty VAT rates ranging from 1 to 350 per cent.
} 
Perhaps the most important limitation of the CE, VP and VRR measures is that the VAT bases used by each ${ }^{7}$ can be very different from real-world VAT bases. For example, Aizenman and Jinjarak (2008) recognize that the CE and VP indexes do not distinguish between the effects of tax evasion and the effects of statutory exemptions. Similarly, De Mello (2009), Bird and Gendron (2007, pp. 62-65), Mathews (2003) and Jack (1996) acknowledge that factors other than tax evasion influence the CE index. These factors include differential VAT rates, differential exemptions, economic activity in the informal sector, and the proportion of imports in total consumption. As a result, the VP, CE and VRR indexes tend to overestimate the extent of noncompliance. ${ }^{8}$ Keen \& Smith (2006) note that as such, results from econometric studies that use these measures should be interpreted with caution.

A more recent class of VAT compliance measure goes some way towards addressing the limitations of the VP, CE, and VRR measures. These measures are variously known as the compliance index (Agha and Haughton, 1996), VAT gap (HM Revenues \& Customs, 2010; Swedish National Tax Agency, 2008), or VAT evasion rate (Gebauer and Parsche, 2003). Hereafter we refer to this class of measure as the compliance index (CI). The CI compares actual VAT revenues with an estimate of the theoretical (or potential) VAT revenue that would be collected in the presence of full compliance. As described in a review by Keen and Smith (2006), the few studies which use the CI calculate the theoretical VAT revenue in a 'top down' manner via a number of steps. First, potential VAT revenue is calculated by multiplying the value of final consumption, classified according to the pattern of

\footnotetext{
7 GDP for the VP index, post-VAT final consumption for the CE index, and pre-VAT final consumption for the VRR index.

${ }^{8}$ For the UK, for example, the VP and the CE were 0.38 and 0.56 respectively for the period 19982000 (Bird and Gendron, 2007, p.231). However estimates by HM Revenues \& Customs of the "VAT gap” for this period were around 15\% (Keen \& Smith, 2006).
} 
VAT rates, with their associated VAT rates. Next, adjustment is made to the initial revenue estimate to account for input-taxed exemptions, and for VAT paid by businesses that are legitimately not registered for VAT. Hence, the CI improves on the CE measure by acknowledging differential VAT rates and bases.

Nevertheless, CI measures also have limitations. As acknowledged by users of the $\mathrm{CI}^{9}$, the macro national accounts data upon which they are calculated may not be sufficiently disaggregated to cleanly map with the multiplicity of differential VAT rates and exemptions. In addition, important features of actual VAT systems remain absent. These features include informal sector activity, and the effect of legal exemption rates and industry VAT registration rates on commodity-specific VAT rates and industry refund rates. Finally, researchers calculating CI-like measures have not, to date, set out a formal framework for calculating the measure that can be readily applied across countries.

The method we propose in this paper is in the CI tradition. However it goes much further, using detailed national accounts supply-use data, together with tax and exemption matrices constructed from the tax code, to develop a more precise estimate of VAT compliance.

\section{A GENERAL FRAMEWORK FOR MEASURING VAT COMPLIANCE}

\section{RATES}

We set out a formal and comprehensive framework for calculating average and base-specific compliance rates. The framework models all statutory and

\footnotetext{
9 See, for example, Agha and Haughton (1996), HM Revenues \& Customs (2010), and Swedish National Tax Agency (2008). Agha and Haughton (1996) acknowledge that they have made simplifying assumptions about the breakdown of consumption expenditure across goods and services. They also assume that the inputs used to produce exempt goods were taxed at the standard VAT rate. HM Revenue \& Customs (2010) and Swedish National Tax Agency (2008) acknowledge that their estimates of the VAT gap are subject to a degree of uncertainty due to both errors contained in the input data itself and the top-down nature of their estimates.
} 
structural elements which affect VAT legal rates and the effective bases on which the VAT is levied. By offering a comprehensive calculation of potential VAT revenue, our measure offers the prospect that the bulk of the difference between potential revenue and actual revenue is due to factors relating to VAT compliance and enforcement, such as administrative inefficiency, tax evasion, tax avoidance and lax enforcement. Hereafter, we refer to our measure as the compliance rate (CR).

VAT is often understood as a tax on final consumption, because VAT paid on inputs to production is refunded. However in practice, the base of the VAT is much broader than final consumption, encompassing elements of production, investment and export ${ }^{10}$. The size of the base on which VAT is ultimately levied depends on a number of factors, including legal exemptions, VAT registration rates, the size of the informal sector, and limitations on VAT credit. Linkages between commodityspecific exemptions and the capacity of industry to reclaim VAT on their inputs are not straightforward if industries exhibit multi-production, and if exemptions on a given commodity differ across users of that commodity. Yet these features of realworld VAT systems are critical to correctly calculating the VAT revenue that a given jurisdiction can reasonably expect to collect from its VAT system as implemented. Giesecke and Tran (2010) outline a formal description of a VAT system that models multi-production, multiple VAT rates, and multiple VAT exemptions. We extend that system in this paper, adding differential VAT registration rates, illegal imports, unclaimed VAT on tourists' purchases, and general and transaction-specific compliance rates.

\footnotetext{
${ }^{10}$ For a detailed discussion on features of VAT systems, see, for example, Ebril et al. (2001).
} 
We assume an economy of $M$ commodities, from $S$ sources, used by $U$ agents. The $U$ agents are comprised of $N$ industries, $K$ capital creators ${ }^{11}$, and $F$ final demanders. The economy and its VAT regime have the following features:

1. Multi-production. We represent this via $S O_{c, j}$, the share of total output of industry $j$ represented by output of commodity $c$; and $S J_{c, j}$, the share of total output of commodity $c$ represented by output of $c$ by industry $j . S O_{c, j}$ and $S J_{c, j}$ can be evaluated from the multi-production matrix of a country’s inputoutput or supply-use tables. In the Vietnam implementation of our system, described in Section 4, $M=113$ and $N=113 .^{12}$

2. Differentiated legislated VAT rates. We represent differences in legislated VAT rates across commodities, sources and users via $L R_{c, s, u}$, a matrix of legislated VAT rates on sales of commodity $c$ from source $s$ to user $u$. In our Vietnam implementation, $U=230$, comprised of 113 industries $(N=113), 113$ investors $(K=113)$ and four final users: households, export, government and stocks $(F=4)$. We will find it helpful to define a subset of $F, D$, which includes only domestic final users, namely households, government and additions to stocks. We evaluate the $113 \times 2 \times 230 L R_{c, s, u}$ matrix through careful inspection of the Vietnamese tax code (National Assembly 2003). Typical values for $L R_{c, s, u}$ are $0,0.05$ and 0.10 .

\footnotetext{
${ }^{11}$ Note that $\mathrm{K}=\mathrm{N}$. That is, investors are also producers.

${ }^{12}$ While the Vietnamese $S O_{c, j}$ and $S J_{c, j}$ matrices are square, they are not diagonal. On the contrary, the Vietnamese economy is characterised by a high level of multi-production.
} 
3. Differentiated VAT legal exemptions for commodities. We model exemptions via $L E X_{c, s, u}$, a coefficient measuring the share of sales of commodity $c$ from source $s$ to user $u$ that are VAT exempt by law. For most flows, $L E X_{c, s, u}$ is zero. $L E X_{c, s, u}$ has a non-zero value where the tax code exempts from VAT some or all of the sales of commodity $c$ to user $u$. For full exemption, $L E X_{c, s, u}$ $=1$. For partial exemption, $0<L E X_{c, s, u}<1$. The latter reflects data aggregation. For example, many countries exempt textbooks. But in most input-output databases, textbooks form part of a broad commodity like "publishing”. We assume that if textbooks are $40 \%$ of "publishing” sales to user $u$, then $L E X_{\text {publishing }, s, u}=0.4 .^{13}$

4. Differentiated degree of VAT registration. We represent the VAT registration rate of producers via $R E G_{j}$, the proportion of industry $j$ 's output that is produced by VAT-registered firms. Businesses may not register for VAT for two reasons. First, VAT codes in many countries allow businesses with revenue or income under a certain threshold to not register for VAT. This is in recognition that VAT compliance costs can be disproportionately high for small businesses, relative to the value of VAT foregone by non-registration. ${ }^{14}$ We represent the proportion of industry j's output produced by legally nonregistered businesses via $N R L_{j}$. Second, many businesses, especially small ones, may chose to operate informally. That is, they may not register as a business in order to avoid paying taxes or social security insurance, or to avoid

\footnotetext{
${ }^{13}$ In this example we also assume that textbooks are the only VAT-exempt component of publishing.

${ }^{14}$ For an extensive discussion of research on VAT compliance costs, see Sandford $(1989,1995)$.
} 
complying with government regulations on labour standards and business reporting. ${ }^{15}$ We represent the proportion of industry j's output produced by informal businesses via $N R I_{j}$.

5. The presence of informal imports. By informal imports we mean imports which are not declared for customs purposes. We assume that informal imports are not subject to VAT. We denote the proportion of imports of commodity $c$ which are informal by $I M_{c}$.

6. Differentiated legal refundability on VAT paid on inputs to capital formation. We use the parameter $\psi_{c, s, j}$ to denote the proportion of VAT paid by industry $j$ $(\mathrm{j} \in K)$ on purchases of $c$ from source $s$ for capital formation that is refunded under the jurisdiction's VAT legislation. Most VAT systems provide for full refund of VAT paid on inputs to capital formation. Hence for most $c, s, j$, $\psi_{c, s, j}=1$. However, an important exception is construction of dwellings. Consistent with long-run input-taxation of dwellings services, most VAT systems provide no refund of VAT paid on inputs to housing construction. This is also true of the Vietnamese VAT system. The Vietnamese system also disallows VAT refunds on specialized equipment used in capital formation by national defense, health and education.

151993 SNA (UN 2001) defines the informal sector as the set of small-scale unincorporated enterprises owned by households which produce at least some products for the market but which either have less than a specified number of employees and/or are not registered under national legislation referring, for example, to tax or social security obligations, or regulatory acts. This informal (or "invisible”) economy, can be sizable in many countries. Schneider (2005) estimates that the informal economy may represent up to 41 per cent of GDP in developing countries, and 17 per cent in OECD countries. 
7. Effective taxation of exports via application of VAT on domestic purchases by non-residents. Under most VAT systems, exports are explicitly zero rated. Nevertheless, domestic non-residents, particularly tourists, pay VAT on their purchases. Recognizing that this represents an application of VAT to exports, many countries provide for some refund of this VAT at the time of the nonresident's departure. Such VAT refund schemes typically only cover a part of the purchases made by domestic non-residents ${ }^{16}$, and even then, many nonresidents may fail to claim their full VAT refund entitlement.

8. The presence of inefficiency in VAT collection. VAT collection inefficiency can arise from tax evasion on the part of registered businesses and lax enforcement by tax authorities. The many ways that VAT can be avoided are well-documented (see for example Ebril et al., 2001; Agha and Haughton, 1996; Keen and Smith, 2006). We denote the degree of compliance in the collection of VAT payable on sales of commodity $c$ from source $s$ to user $u$ by the transaction-specific compliance rate $C R T_{c, s, u}\left(0<C R T_{c, s, u}<1\right)$.

The VAT model embodying these eight characteristics is described by equations (E1) - (E17) (see Figure 1). Note that our VAT model is comprised of two parts: equations (E1) - (E17) represents the core of the VAT model, while equations (E18) - (E44) calculate from this core model useful summary measures for reporting. Our VAT model begins with (E1), which defines actual VAT collected on purchases of commodity $c$ from source $s$ by user $u\left(\mathrm{VAT}_{\mathrm{c}, \mathrm{s}, \mathrm{u}}\right)$ as the product of the

\footnotetext{
${ }^{16}$ See, for example, the UK VAT regulation on this issue (HM Revenue \& Customs 2004). Typically, travelers can claim VAT on purchases which exceed a certain value and are taken out of the country. But they cannot claim VAT on goods or services which are consumed inside the country, such as meals, travel and hotel expenses.
} 
relevant legal VAT rate $\left(\mathrm{LR}_{\mathrm{c}, \mathrm{s,u}}\right)$, the transaction's theoretical VAT base $\left(\operatorname{TBASE}_{c, s, u}\right)$ and a transaction-specific compliance rate $\left(\mathrm{CRT}_{\mathrm{c}, \mathrm{s}, \mathrm{u}}\right)$. (E2) calculates aggregate actual VAT revenue (VATTOT) as the sum of actual VAT revenue collected on each commodity-, source- and agent-specific transaction ( $\mathrm{VAT}_{\mathrm{c}, \mathrm{s,u}}$ ).

(E3) defines the average economy-wide VAT compliance rate (CR) as the ratio of aggregate actual VAT revenue (VATTOT) to aggregate theoretical VAT liabilities (TVATOT).

(E4) calculates aggregate theoretical VAT collections as the sum of theoretical VAT liabilities on sales to domestic agents (TVATDOM) and foreign agents (TVATEXP). By theoretical collections, we mean that revenue which the tax authority should anticipate collecting, if it were to take into account all known or knowable features of the tax code and the economy's structure. Equations (E5) (E17) embody the features of tax law and economic structure relevant to calculation of theoretical VAT revenue.

(E5) calculates theoretical VAT liabilities accruing on commodity- and source-specific sales to domestic agents as the sum of the product of each theoretical tax base $\left(\right.$ TBASE $\left._{c, s, u}\right)$ and legislated VAT rate $\left(\mathrm{LR}_{\mathrm{c}, \mathrm{s}, \mathrm{u}}\right)$. Aggregate expected VAT liabilities accruing on export sales (TVATEXP) are calculated by (E6). Calculation of TVATEXP is complicated by domestic purchases by non-residents, such as tourists. Non-residents, at the time of their departure, can often claim refund of some VAT paid on their domestic purchases. In (E6), the value of these reimbursements is represented by NRESREF. The remainder of (E6) recognizes that the potential VAT base for exports can be divided into two components: domestic sales to nonresidents, and foreign sales. The proportion of each commodity- and source-specific 
export sale represented by sales to domestic non-residents is denoted by SHNRES S $_{c,}$. In (E6), we assume that such transactions attract VAT at the legislated VAT rate for households. The remaining export sales attract VAT at the legislated VAT rate for export sales, which will generally be zero under most VAT systems. Note that (E6) contains a dummy variable, D. This variable is helpful in the simulations we report in Section 5. Typically, D is set at 1 . However in Section 5, it will prove helpful to initially set the value of $\mathrm{D}$ at 0 . As we shall see, this facilitates an initial calibration of our model such that it exactly reproduces the assumptions underlying the VRR measure.

(E7) calculates the value of the transaction base on which VAT may potentially be levied ( $\operatorname{VBASE}_{\mathrm{c}, \mathrm{s}, \mathrm{u}}$ ). Depending on the specifics of each country's VAT legislation, this base can be the basic value of the transaction only ( BASIC $_{\mathrm{c}, \mathrm{s}, \mathrm{u}}$ ), or it may also include certain taxes $\left(\mathrm{T}_{\mathrm{c}, \mathrm{s,u}}\right)$ and margins $\left(\mathrm{M}_{\mathrm{c}, \mathrm{s,u}}\right)$ accruing on the transaction. ${ }^{17}$ (E7) allows for both possibilities.

Equations (E8) - (E10) define the concept of a theoretical VAT base, TBASE $_{c, s, u}$. By theoretical VAT base, we mean the value of transactions subject to VAT after having taking into account all legal exemptions, legal registration rates, informal activity, and the production and sales structure of economic activity. The theoretical bases for VAT on purchases of inputs to current production, capital formation, and final demand are defined by equations (E8), (E9) and (E10) respectively. In each case, the theoretical base is the product of the value of the transaction base potentially subject to VAT and a set of coefficients describing

\footnotetext{
${ }^{17}$ For most countries, the VAT transaction base is the basic value of the relevant transaction, plus all relevant trade, transport, insurance and other margins. For Vietnam, the value of the transaction base also includes an indirect tax known as Special Consumption Tax.
} 
exemption rates $\left(\mathrm{EX}_{c, s, \mathrm{u}}\right)$ and refund factors $\left(\phi_{j}^{(1)}, \phi_{c, s, k}^{(2)}\right)$. The latter coefficients are defined by equations (E11) - (E16).

(E11) defines $\phi_{j}^{(1)}$, the VAT refund factor on purchases of intermediate inputs into current production. When producer $j$ buys input $c$ from source $s$, it must pay a VAT rate equivalent to the legislated rate less the exemption proportion applicable to $(c, s)$ and $j$. Industry $j$ then reclaims this tax, but only to the extent input $(c, s)$ is used to produce non-exempt goods, and even then, only to the extent that firms in industry $j$ are registered for VAT. Industry $j$ 's capacity to reclaim VAT paid on inputs is modeled by the refund factor, $\phi_{j}^{(1)}$, defined by (E11) as the proportion of industry j's VAT payments on inputs to production that is refunded by the tax authority. In (E11) we first see the VAT registration rate, $R_{E G}$, in recognition that only registered firms can reclaim VAT paid on their inputs. The remainder of (E11) recognizes that to calculate $\phi_{j}^{(1)}$ we need to look to three dimensions of industry $j$ 's sales: what it produces, to whom it sells, and whether the sales are VAT exempt. Data on the first dimension is provided by $S_{c, j}$, already discussed above. For the second dimension, we introduce $S S_{c, u}$, the share of total sales of commodity $c$ sold to user $u$. We can evaluate $S S_{c, u}$ from row shares in an input-output database. For the third dimension, we represent the extent of non-exempt sales by $\left[1-\mathrm{LEX}_{\mathrm{c}, \mathrm{u}}\right]$.

Equation (E12) defines VAT registration rates, REG $_{\mathrm{j}}$. (E12) recognizes two influences on industry-specific VAT registration rates. The first is the size of the informal sector, represented in (E12) by $\mathrm{NRI}_{j}$, which measures the proportion of industry j's activity generated by firms in the informal sector. The second is legal 
non-registration, represented in (E12) by $\mathrm{NRL}_{\mathrm{j}}$, the proportion of industry $j$ 's output produced by firms that are legally permitted not to register for VAT.

The non-taxed proportion of commodity $c$ from source $s$ to user $u$, which we denote by the exemption factor $\mathrm{EX}_{\mathrm{c}, \mathrm{s}, \mathrm{u}}$, is defined by (E13) as the maximum value of two measures: the legal exemption rate $\mathrm{LEX}_{\mathrm{c}, \mathrm{s}, \mathrm{u}}$, and the de facto exemption rate due to non-registration or illegal imports, $\mathrm{DEX}_{\mathrm{c}, \mathrm{s}}$. For example, Vietnam's VAT law stipulates that exports of mining are VAT exempt, hence $\mathrm{LEX}_{\text {mining, domestic, export }}=1$. Thus, via (E13), $\mathrm{EX}_{\text {mining, domestic, export }}=1$, regardless of how many mining producers register for VAT (that is, regardless of the value for $\mathrm{DEX}_{\text {mining, domestic }}$ ).

Equation (E14) models de facto exemption arising from non-registration. For example, alcohol might be fully VAT-taxed (i.e. $\operatorname{LEX}_{\text {alcohol,s,u }}=0$ ), but $10 \%$ of domestic alcohol producers may fail to register for VAT (i.e. $\sum_{\mathrm{j}} \mathrm{SJ}_{\text {alcohol, } \mathrm{j}} \times \mathrm{REG}_{\mathrm{j}}=$ 0.90). Hence, via (E14), $\mathrm{DEX}_{\text {Alcohol,Domestic }}=0.10$. Then, via (E13), $\mathrm{EX}_{\text {alcohol, domestic }}=$ 0.10, allowing $10 \%$ of domestically-produced alcohol to escape VAT. De facto VAT exemption may also arise on imported commodities. We denote the proportion of imports that are not declared for tax purposes by $\mathrm{IM}_{\mathrm{c}}$. Continuing with our example, if all imported alcohol is legally imported (that is, $\mathrm{IM}_{\text {alcohol }}=0$ ) then, via (E13) and (E15), $\mathrm{EX}_{\text {alcohol, import }}=0$. However, if $20 \%$ of alcohol is imported illegally, in the sense that it is undeclared to tax authorities, then $\mathrm{EX}_{\text {alcohol, import }}=0.2$.

Equation (E16) defines $\phi_{c, s, k}^{(2)}$, the effective VAT refund rate on inputs of commodity $c$ from source $s$ into capital formation by industry $k$. (E16) recognizes that the effective refund rate for industry $k$ depends not only on the legal refund rate 
allowed by the tax authority $\left(\psi_{c, s, k}\right)$, but also on industry $k$ 's registration rate, because only registered firms can claim credit on VAT paid on investment inputs.

Equation (E17) defines transaction-specific compliance rates $\left(\mathrm{CRT}_{\mathrm{c}, \mathrm{s}, \mathrm{u}}\right)$ as the product of two shift variables: one transaction-specific $\left(\mathrm{FCRT}_{\mathrm{c}, \mathrm{s,u}}\right)$ and one economywide ( FCR ). Typically, in the initial calibration of the model, one of either FCRT $_{c, s, u}$ or FCR will be endogenous, with the value of the other set exogenously at 1 . Which of FCRT $_{c, s, u}$ or FCR is determined endogenously depends on availability of actual VAT revenue information. If a full set of values for $\mathrm{VAT}_{c, s, u}$ are available from the tax authority, then $\mathrm{VAT}_{c, s, u}$ can be set exogenously at these known values, with $\mathrm{FCRT}_{c, \mathrm{~s}, \mathrm{u}}$ endogenous and FCR exogenously set equal to 1. A more common scenario will be that information on aggregate VAT collections (VATTOT) is available, but not information on $\mathrm{VAT}_{\mathrm{c}, \mathrm{s,u}}$. In this case, $\mathrm{VAT}_{\mathrm{c}, \mathrm{s,u}}$ and FCR will be endogenous, with VATTOT exogenously set at its known value and FCRT $_{c, s, u}$ exogenously set equal to 1 . Another possibility is that VATTOT is known, and selected elements of $\mathrm{VAT}_{\mathrm{c}, \mathrm{s}, \mathrm{u}}$. In this case, selected elements of $\mathrm{VAT}_{\mathrm{c}, \mathrm{s}, \mathrm{u}}$ (together with VATTOT) can be set exogenously at known values, with endogenous determination of both corresponding elements of FCRT $_{c, s, u}$ and FCR.

\section{PARAMETERISING THE VAT MODEL TO VIETNAM'S VAT SYSTEM}

We illustrate of our VAT theory by applying it to the Vietnamese VAT system. Vietnam makes an interesting case study for at least two reasons. First, with its many rates and exemptions, Vietnam's VAT system is arguably among the most complex in South East Asia (Giesecke and Tran, 2010). This complexity ensures that 
our Vietnamese implementation exercises many of the dimensions of the system described by (E1) - (E17). Second, existing estimates of CE for Vietnam are low. Our system helps explain why. In Section 5 we compare our measure of VAT compliance (CR) to values for collection efficiency (CE) and its more refined variant, the VAT Revenue Ratio (VRR). We decompose the gap between CR and VRR into the individual contributions of the structural and statutory factors that characterize Vietnam's VAT system. The computer implementation of our equation system uses the GEMPACK software (Harrison and Pearson, 1996).

Vietnam introduced a VAT in 1999. By 2005 the system had undergone much change, while still retaining a high degree of complexity. Vietnam's VAT has three rates, many exemptions across different commodities and purchasers, and numerous limits on refunds on inputs to investment. The nature of Vietnam's implemented VAT system is further complicated by the country's economic structure, which is characterized by a high degree of multi-production and diverse VAT registration rates across industries.

To implement our VAT system, we require independent estimates for the system's exogenous variables, namely BASIC $_{c, s, u}, \operatorname{IM}_{c}, \operatorname{LEX}_{c, s, u}, \operatorname{LR}_{c, s, u}, \psi_{c, s, k}$, $\mathrm{M}_{\mathrm{c}, \mathrm{s}, \mathrm{u}}, \mathrm{NRI}_{\mathrm{j}}, \mathrm{NRL}_{\mathrm{j}}, \mathrm{SO}_{\mathrm{c}, \mathrm{j}}, \mathrm{SJ}_{\mathrm{c}, \mathrm{j}}, \mathrm{SS}_{\mathrm{c}, \mathrm{u}}, \mathrm{T}_{\mathrm{c}, \mathrm{s}, \mathrm{u}}, \mathrm{NRESREF}, \mathrm{SHNRES}_{\mathrm{c}, \mathrm{s}}, \mathrm{FCRT}_{\mathrm{c}, \mathrm{s}, \mathrm{u}}$ and VATTOT ${ }^{18}$ Of these, BASIC ${ }_{c, s, u}, M_{c, s, u}, S O_{c, j}, S_{c, j}$ and $\mathrm{SS}_{c, u}$ are readily calculated from national input-output data (GSO , 2007). All elements of FCRT $\mathrm{c}_{\mathrm{c}, \mathrm{s}, \mathrm{u}}$ are set equal to 1 . VATTOT and NRESREF are available from government finance

\footnotetext{
18 Estimates for $\mathrm{VAT}_{\mathrm{c}, \mathrm{s}, \mathrm{u}}$ are not available for Vietnam. However, the value of total VAT collections is available. Hence, we determine VATTOT as an exogenous variable, with $\mathrm{VAT}_{\mathrm{c}, \mathrm{s}, \mathrm{u}}$ and FCR endogenous. All elements of $\mathrm{FCR}_{\mathrm{c}, \mathrm{s}, \mathrm{u}}$ are exogenously set equal to 1 .
} 
statistics (Ministry of Finance, 2007). $\operatorname{LEX}_{\mathrm{c}, \mathrm{s}, \mathrm{u}}, \mathrm{LR}_{\mathrm{c}, \mathrm{s}, \mathrm{u}}$ and $\psi_{c, s, \mathrm{k}}$ are determined by careful inspection of the tax code (National Assembly, 2003). $\mathrm{T}_{\mathrm{c}, \mathrm{s}, \mathrm{u}}$ is determined via inspection of both the tax code (to identify relevant taxes) and input-output statistics (to determine tax rates). Estimates for the remaining variables $\mathrm{IM}_{\mathrm{c}}, \mathrm{NRI}_{\mathrm{j}}, \mathrm{NRL}_{\mathrm{j}}$ and SHNRES $_{\mathrm{c}, \mathrm{s}}$ must be developed from other data sources. In the following subsections, we expand on our discussion of the values for the model's exogenous variables. Before doing so, we draw the reader's attention to Tables 1 and 2 . These tables summarize relevant features of Vietnam's VAT system and economic structure, while abstracting from the details of our fully implemented system of VAT equations. Table 1 reports the key values that determine the outcome for the compliance rate, CR. The values reported in columns (1) - (7) are calculated by (E18) - (E44) as appropriate weighted averages and totals of values from the core equation system (E1) - (E17). To aid our understanding of the values in Table 1, Table 2 reports the commodity composition of purchases by the four broad agents in our model, namely producers, investors, households, and government.

\subsection{Legal VAT rates}

Equations E18 - E20 define average legal rates classified by broad economic agent $\left(\operatorname{AVELR}_{\mathrm{q}}\right)$. We report Vietnam’s $\operatorname{AVELR}_{\mathrm{q}}$ values in Table 1, column 1.

Vietnam introduced VAT in January 1999. The VAT was initially levied at four rates: 0, 5, 10 and 20\%. Since January 2004, the VAT rate structure has been simplified to three rates: 0,5 and $10 \%$. Sales to exports and additions to stocks attract the zero VAT rate. As such, we do not report summary VAT measures for exports and stocks in Table 1 . The 5\% rate attaches to unprocessed agricultural commodities at the commercial trading stage, certain primary building materials, chemicals, 
fertilisers, pharmaceuticals, certain machinery, metal products, animal feed, publishing, water, road transport, rail transport, air transport, scientific services, and cultural services. All other goods and services are taxed at $10 \%$.

Average legal VAT rates differ across users, reflecting differences in the commodity composition of their purchases. The average VAT rate is lowest for government consumption (row 4, column 1, Table 1). This is because the bulk of government spending is on services (row 3, column 4, Table 2) most of which are either VAT exempt (e.g. education, health care, and public administration), or are subject to the $5 \%$ rate (e.g. scientific and cultural services). Average rates are higher for households, investors and producers (rows 1-3, column 1, Table 1) because larger shares of their spending are on commodities that attract $10 \%$ VAT rates, such as mining, manufacturing and construction (see Table 2).

\subsection{Legal exemption rates}

The Vietnamese VAT code provides VAT exemptions for goods and services deemed either essential or important for economic development. These include raw agricultural materials, imported machinery and equipment used in R\&D and capital formation, health and education services, public broadcasting, cultural events and sanitation works. Exemptions also apply to difficult-to-tax services, such as financial and dwellings services. Export sales of mining are explicitly declared VAT exempt, despite the zero rate applying to all export sales.

Equations (E21) - (E23) calculate average legal exemption rates $\left(\right.$ AVELEX $\left._{q}\right)$ for broad categories of commodity user. Column 2, Table 1 reports AVELEX values for Vietnam. Average legal exemption rates differ across users because of differences in the commodity composition of their consumption. Government has the 
highest average legal exemption rate (84\%), reflecting high consumption of exempted services, such as education and health. Average legal exemption rates for producers and households are substantially lower, at around $20 \%$. This reflects the comparatively high proportions of the total spending by these agents on manufactures, most of which are not VAT exempt. Investment has the lowest average legal exemption rate because a large share of investment spending is on construction services, which are not VAT exempt.

\subsection{Non-registration rates}

As discussed in Section 3, industry-specific registration rates are influenced by two factors: non-registration for VAT purposes permitted under the VAT code; and non-registration arising from informal activity. The rates of these two sources of non-registration are represented by $\mathrm{NRL}_{\mathrm{j}}$ and $\mathrm{NRI}_{\mathrm{j}}$ respectively (see equation E12). We discuss below how the initial levels of these variables were calculated for our Vietnam implementation.

Under the Vietnamese VAT code, individuals, households and enterprises conducting business in Vietnam are obliged to register for VAT. Because VAT registration is generally compulsory ${ }^{19}$, we set $\mathrm{NRL}_{\mathrm{j}}$ equal to 0 .

Vietnam has many enterprises that choose to operate informally, failing to register for VAT, and not registering as businesses under other relevant statutes. We base our estimates for $\mathrm{NRI}_{\mathrm{j}}$ on the size of the informal sector. However by its nature,

\footnotetext{
19 The one exception to compulsory VAT registration is "household businesses" with monthly income less than approximately US \$22 per month. While there is no official data on either the number or importance of these businesses, we expect both to be small. In forming this view, we noted two things. First, as "household businesses" we expect activity by such enterprises to represent very small shares of industry-specific activity levels. Second, the legislated threshold for VAT registration by such enterprises (US \$22 per month) is very low - less than half average income per capita (US \$52 per month). Hence, we expect very few household businesses to fall under this category, and to the extent they do, their existence (and influence on $\mathrm{REG}_{\mathrm{j}}$ ) will likely be captured in our $\mathrm{NRI}_{\mathrm{j}}$ estimate.
} 
the size of the informal sector is difficult to measure. Estimates of Vietnam's informal sector have ranged between 30\% of GDP in 1995 (Nguyen Van Chinh 2001) and 16\% of GDP in 2005 (Shneider and Buehn 2007).

There are no estimates of the informal sector at the industry level. However, we have industry-specific data on production by individual household businesses ${ }^{20}$, and the proportion of these individual household businesses which have official registration as a business. We use the share of industry $j$ 's activity produced by nonregistered individual household businesses as a proxy for the share of industry j's activity produced by the informal sector. ${ }^{21}$ That is, we calculate the share of industry j’s output produced by informal enterprises $\left(\mathrm{NRI}_{\mathrm{j}}\right)$ via:

$$
\mathrm{NRI}_{\mathrm{j}}=\mathrm{SHIB}_{\mathrm{j}} \times \mathrm{SHNR}_{\mathrm{j}}
$$

where SHIB $_{j}$ is the share of industry j's output produced by individual household businesses; and $\mathrm{SHNR}_{\mathrm{j}}$ is the share of the individual household businesses in industry $j$ that are not registered for business purposes. We base our $\mathrm{SHIB}_{\mathrm{j}}$ and SHNR $_{\mathrm{j}}$ estimates on data from GSO(2005), GSO(2006a) and GSO(2006b). ${ }^{22}$

${ }^{20}$ An individual household business is a business of fewer than 10 employees that is owned by one individual or a household. In 2007, the average size of individual household businesses was 1.76 persons (GSO 2008).

${ }^{21}$ This is consistent with standard definitions of the informal sector, which is typically seen to consist of small-scale unincorporated enterprises owned by households (for example, see the definition of the informal sector in 1993 SNA (UN 2001)).

${ }^{22}$ For those industries classified as industrial, we base values for SHIB $_{j}$ on data from GSO (2006a), which classifies output by industry into output produced by five types of enterprise (individual household businesses, state-own enterprises, collective, private, and enterprises with foreign capital). For industries in the agricultural and service sectors, we use data from the Vietnam Household Living Standard Survey 2004 (GSO 2006b), defining SHIB $_{\mathrm{j}}$ as the share of industry $j$ 's labour income that accrues to self employed persons in industry $j$. We calculate $\mathrm{SHNR}_{\mathrm{j}}$ for industries in the industrial and service sectors using data from the Annual Non-farm Household Business Survey (GSO 2005), which provides information on the registration and tax payment status of individual household businesses. For industries in the agricultural sector, we base our $\mathrm{SHNR}_{\mathrm{j}}$ estimate on the proportion of agricultural households operating in industry $\mathrm{j}$ that do not pay taxes, data for which is obtained from the VHLSS (GSO 2006b). 
Weighting our $\mathrm{NRI}_{\mathrm{j}}$ estimates by industry output shares, we find the economy-wide average non-registration rate is $22 \%$. This lies within the range of existing estimates of the size of the Vietnamese the informal sector. At the sectoral level, non-registration rates range from approximately $80 \%$ in agriculture, $20 \%$ in services, $10 \%$ in manufacturing, to below $3 \%$ for mining, construction and utilities.

Equations (E24)-(E26) calculate economy-wide average de facto exemptions

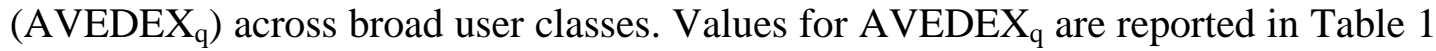
(column 3). As can be seen from column 3, non-registration generates de facto exemptions on purchases by all users. For example, if $83 \%$ of agricultural products are produced by non-registered producers, then the de facto exemption rate for agricultural products is $83 \%$ for all users.

Equations (E27)-(E29) calculate average effective rates of exemption on the purchases of broad user classes $\left(\mathrm{AVEEX}_{\mathrm{q}}\right)$. Values for $\mathrm{AVEEX}_{\mathrm{q}}$ are reported in Table 1, column 4. Via equation (E13) the effective exemption rate for any given commodity is the maximum of its legal exemption rate and its de facto (nonregistration generated) exemption rate. In Table 1, this accounts for why the average effective exemption rate for each user (column 4) always exceeds the value of the simple average of the user's average legal exemption rate (column 2) and average de facto exemption rate (column 3).

\subsection{Refund rates for inputs into production and investment}

Equations (E30) and (E31) calculate weighted average rates of VAT credit paid on inputs to production and investment (AVEREF1 and AVEREF2 respectively). Values for AVEREF1 and AVEREF2 are reported in Table 1, column

5. On average, approximately $75 \%$ of VAT paid on inputs to production are refunded 
(row 1, column 5, Table 1). There are some additional limits on VAT credit to investment. For example, VAT credit is unavailable on inputs to housing construction, and use of specialized equipment and machinery in capital formation by public administration, health and education. Together, these additional credit limits cause the average refund rate on inputs to investment, at $70 \%$, to be lower than that for inputs to production (row 2, column 5, Table 1).

\subsection{Theoretical base and theoretical VAT liabilities}

Equations (E32)-(E34) calculate aggregate VAT theoretical bases classified by broad user type (TBASE ${ }_{q}$ ). Equations (E35)-(E37) calculate theoretical VAT liabilities by broad user type $\left(\mathrm{TVAT}_{\mathrm{q}}\right)$. Values for $\mathrm{TBASE}_{\mathrm{q}}$ and $\mathrm{TVAT}_{\mathrm{q}}$ are reported in columns (6) and (7) respectively of Table 1. As can be seen from columns (6) and (7), the incidence of VAT falls not only on final consumption, but also on production and investment. The theoretical VAT liabilities on final consumption account for about $60 \%$ of total theoretical VAT liabilities. The remaining VAT liabilities accrue on sales to production and investment, accounting for 29 and 11\% of total VAT liabilities respectively.

\section{FROM CE TO CR: DECOMPOSING THE DIFFERENCE} BETWEEN VIETNAM'S INDICES OF COLLECTION EFFICIENCY AND COMPLIANCE RATE

In 2005, total Vietnamese VAT revenue was VND 45.9 trillion, the value of final consumption was VND 649.2 trillion, and the value of VAT-exclusive final consumption was VND 621.8 trillion. Hence, Vietnam's collection efficiency (CE) 
index was $0.71(=45.9 / 649.2 \times 0.10){ }^{23}$ The country’s VAT Revenue Ratio (VRR) was $0.74(=45.9 / 621.8 \times 0.10)$. As indicators of Vietnamese VAT compliance, these indices are low and misleading. As we shall discuss further in this section, the application of equations (E1) - (E17) to Vietnam produces a compliance rate (CR) value for Vietnam of 0.85 . This is a full eleven percentage points higher than the VRR index because the CR calculation takes account of the statutory and structural features of Vietnam's VAT system. In this section, we investigate the gap between Vietnam's VRR and CR indices, exploring the individual contributions of multiple rates, exemptions, registration rates, investment input credits, and taxation of nonresidents. In doing so, we use the decomposition algorithm of Harrison et al. (2000) as implemented in the GEMPACK software (Harrison and Pearson, 1996). ${ }^{24}$ We begin by parameterising our VAT model in a way that reflects the implicit assumptions of the VRR calculation. The VRR-implicit values for the exogenous variables are:

${ }^{23}$ Bird and Gendron (2007) report a much lower collection efficiency ratio for Vietnam in the period 1998-2000, at 0.56. The difference is likely due to low compliance at the time of the Bird and Gendron study, when the tax was still very novel for both tax payers and tax authorities (Vietnam introduced the VAT in 1999).

${ }^{24}$ For the case of one endogenous variable, Z, Harrison et al. (2000) summarise their decomposition algorithm as follows. Assume $\mathrm{Z}$ can be expressed as a function of $n$ exogenous variables $\mathrm{X}_{1}, \mathrm{X}_{2}, \ldots \mathrm{X}_{\mathrm{n}}$ : $Z=f\left(X_{1}, X_{2}, \ldots X_{n}\right)$. Next, assume that the vector of exogenous variables $X=\left(X_{1}, X_{2}, \ldots, X_{n}\right)$ moves along some path, beginning at $\mathrm{X}_{\mathrm{INITIAL}}$ and ending at $\mathrm{X}_{\mathrm{FINAL}}$ :

$\mathrm{X}_{\text {INITIAL }}=\left(\mathrm{X}_{10}, \mathrm{X}_{20}, \ldots, \mathrm{X}_{\mathrm{n} 0}\right)$

$\mathrm{X}_{\mathrm{FINAL}}=\left(\mathrm{X}_{11}, \mathrm{X}_{21}, \ldots, \mathrm{X}_{\mathrm{n} 1}\right)=\left(\mathrm{X}_{10}+\Delta \mathrm{X}_{1}, \mathrm{X}_{20}+\Delta \mathrm{X}_{2}, \ldots, \mathrm{X}_{\mathrm{n} 0}+\Delta \mathrm{X}_{\mathrm{n}}\right)$

Assume that the shocks are divided into $h$ equal instalments. Provided $h$ is sufficiently large, the effect of applying the $1 / h^{\text {th }}$ instalment of the total shock can be accurately approximated by:

$d Z=f_{1} d X_{1}+f_{2} d X_{2}+\ldots+f_{n} d X_{n}$, where $f_{i}=\delta f / \delta X_{i}$ and $d X_{i}=\Delta X_{i} / h$.

If $h$ is sufficiently large (ie the $\mathrm{dX}_{\mathrm{i}}$ are sufficiently small) then the approximation will be exact and the right hand side terms provide a decomposition of the total change $\mathrm{dZ}$ for the first installment of the shock. Going on to apply the remaining $h-1$ installments of the shocks, the $f_{i}$ depend on the value of $Z$ and $\mathrm{X}$ at each step, and so change with each step. This provides no additional computational burden for GEMPACK, since updated values for the $f_{i}$ 's are required for the standard GEMPACK solution algorithm. Finally, the contribution made by each shock $\Delta \mathrm{X}_{\mathrm{i}}$ to the total change in $\mathrm{Z}(\Delta \mathrm{Z})$ is the sum of the $h$ results for $\mathrm{f}_{\mathrm{i}} \mathrm{dX}_{\mathrm{i}}$. In the above example, and in the algorithm implemented in GEMPACK by Harrison et al., exogenous variables are assumed to move on a straight line path from their pre- to post-simulation values. Other paths may be possible, but as Harrison et al. argue, a straight-line path will typically be the most natural choice from among the many possible paths. 
$\mathrm{LR}_{\mathrm{c}, \mathrm{s}, \mathrm{u}}=0.10$

$\mathrm{LEX}_{\mathrm{c}, \mathrm{s}, \mathrm{u}}=0$

$\Psi_{c, s, k}=1$

$\mathrm{NRI}_{\mathrm{j}}=0$

$\mathrm{NRL}_{\mathrm{j}}=0$
$\mathrm{IM}_{\mathrm{c}}=0$

SHNRES $_{\mathrm{c}, \mathrm{s}}=0$

$\mathrm{T}_{\mathrm{c}, \mathrm{s}, \mathrm{u}}=0$

NRESREF $=0$

$\mathrm{D}=0$

With our VAT model parameterized in this way, we find CR $=0.74$, that is, our full VAT model begins by exactly reproducing the crude VRR value. Next, we run a simulation in which we move values for relevant variables to their true values. In particular, we move $\operatorname{LEX}_{c, s, u}, \quad \operatorname{LR}_{c, s, u}, \quad \psi_{c, s, k}, \quad T_{c, s, u}, \quad \operatorname{IM}_{c}, \quad \mathrm{NRI}_{\mathrm{j}}$, $\mathrm{NRL}_{\mathrm{j}}, \mathrm{SHNRES}_{\mathrm{c}, \mathrm{s}}$, NRESREF and D from their VRR-implicit values, to their true values. In so doing, we employ the decomposition method of Harrison et al. (2000) to identify the individual contributions of each of these exogenous variables to the gap between Vietnam's VRR index and its CR index.

Table 3 presents a summary of our decomposition simulation. Column (1) summarizes the pre-simulation status of the model, with exogenous variables set at values that replicate implicit VRR assumptions. With exogenous variables set at their VRR-implicit values, the aggregate theoretical VAT base on domestic users (TVATDOM) is VND 621.8 tr. With all legal rates set at 0.10 , expected VAT revenue is VND 62.2 tr., and the value for CR is 0.74 .

Our simulation involves moving the values for $\operatorname{LEX}_{c, s, u}, \mathrm{LR}_{c, s, \mathrm{u}}, \psi_{c, s, k}, \mathrm{~T}_{\mathrm{c}, \mathrm{s}, \mathrm{u}}$, $\mathrm{IM}_{\mathrm{c}}, \mathrm{NRI}_{\mathrm{j}}, \mathrm{NRL}_{\mathrm{j}}, \mathrm{SHNRES}_{\mathrm{c}, \mathrm{s}}$, NRESREF and D from their VRR-implicit values to their true values. This changes the values for the model's endogenous variables, including theoretical bases TBASE $_{\mathrm{c}, \mathrm{s}, \mathrm{u}}$ ), theoretical VAT liabilities (TVATTOT) and the outcome for our economy-wide compliance measure, CR. Results for these variables are summarized in Table 3. The decomposition simulation allows the 
outcomes for these variables to be decomposed into the individual contributions made by the movements of each of the exogenous variables from their VRR-implicit values to their true values. In our simulation, over a hundred thousand exogenous variables are shocked, hence some aggregation is necessary for reporting purposes. This is achieved by aggregating the individual effects of each of the exogenous shocks within four groups of related variables. These groups correspond to columns 2 - 6 of Table 3. Each column shows the effects of a group of shocks to the endogenous variables in isolation of the effects from other groups of shocks ${ }^{25}$. The decomposition procedure ensures that the sum of the contributions from all groups to an endogenous variable equals the total change of the variable. As can be seen from row 8, columns 2 - 6, the bulk of the difference between the VRR and CR indices is explained by Vietnam's differentiated legal VAT rates and numerous legal VAT exemptions. Business non-registration (column 4), selectivity of refund on VAT incurred in investment (column 5), and VAT on non-resident domestic purchases (column 6) explain relatively little of the difference between the VRR and CR measures. In the subsections below we examine these effects, focusing on the main drivers of the results in each column of Table 3.

\footnotetext{
${ }^{25}$ Note, however, that in a multi-step Euler computation, the effects of shocks in each column are largely, but not completely, independent of shocks in other columns. The decomposition algorithm calculates an exogenous variable's contribution to the total outcome for a given endogenous variable by summing its contributions as it moves along a path from its pre- to post-shock value. This requires, along this path, continuous re-evaluations of the endogenous variable's elasticity to the exogenous variable in question. These elasticities will be somewhat dependent on movements in other shocked variables. Hence, the effects of a given shock in a given column are largely, but not completely, independent of shocks in other columns. This is apparent in the results for the effects of shocks on the weighted average of legal rates (row 1, Table 3). The legal rate shown on this row is the economywide average VAT rate, weighted by the theoretical base of the VAT. One might expect that the introduction of legal exemptions, non-registration and investment input refunds would have no effect on the average legal rate. That is, the values in columns $3-6$, row 1 , are expected to be zero. We see this outcome in columns 4 to 6 , but not column 3 . Row 1 , column 3 , differs slightly from zero because the theoretical VAT base changes significantly in this column. This affects the weighting regime underlying the calculation of AVELRTOT.
} 


\subsection{Legal rates}

In column 1 of Table 3, VAT rates are set at the standard Vietnamese rate of $10 \%$, allowing our system to reproduce the VRR calculation. However, Vietnam levies a non-standard VAT rate of 5\% on a number of commodities (see Section 4.1 above). Among other shocks, our simulation involves moving the values for $\operatorname{LR}_{c, s, u}$ from their VRR-implied values of 0.10 to their true values. Column 2 isolates the contribution of Vietnam's non-standard VAT rates on the difference between the VRR and CR measures.

In moving $\mathrm{LR}_{\mathrm{c}, \mathrm{s}, \mathrm{u}}$ to their true values, AVELRTOT (Vietnam's average legal VAT rate) falls by 1.5 percentage points (row 1, column 2). With column 2 isolating the effects of movements in $\operatorname{LR}_{c, s, \mathrm{u}}$ to their true values, we see no changes in the values of AVELEXTOT, AVEDEXTOT, AVEEXTOT and TBASETOT (rows 2 5). However with legal rates moved to their true values, theoretical VAT liabilities (TVATTOT) fall by approximately VND 10 trillion (row 6). This explains over 12 percentage points of the gap between the VRR and CR measures (row 8, column 2).

The Harrison et al. (2000) decomposition allows for column 2 to be decomposed further: as far as the individual contributions of the movements in each element of $\mathrm{LR}_{\mathrm{c}, \mathrm{s}, \mathrm{u}}$. We suppress this detail here. However, we note below the main contributors to the column 2 result.

Most agricultural commodities attract VAT at 5\%. Hence, agricultural commodities have the largest difference between VRR-implicit and actual values for $\mathrm{LR}_{\mathrm{c}, \mathrm{s}, \mathrm{u}}$. However, agricultural commodities make up less than $13 \%$ of the final consumption base (see columns 3 and 4, Table 2). As such, non-standard VAT rates on agriculture explain about -0.6 percentage points of the -1.6 percentage point 
movement in AVELRTOT, and thus explain just over one-third of the 12.3 percentage point contribution of non-standard legal rates to the difference between VRR and CR.

Non-standard VAT rates on certain manufactured goods make the largest contribution to the fall in AVELR. A number of important consumption items, such as sugar, pharmaceuticals, chemical products, printing and publishing products, are taxed at the concessional rate of $5 \%$, not the standard rate of $10 \%$. In moving $\mathrm{LR}_{\mathrm{c}, \mathrm{s}, \mathrm{u}}$ to their true values, the average VAT rate on manufactures falls by 1.6 percentage points. Manufactured products represent about $45 \%$ of total final consumption base for VAT (see row 3, columns 3 and 4, Table 2). Hence, the fall in the average VAT rate on manufactures explains about -0.8 percentage points of the -1.5 percentage point movement in AVELR, and thus accounts for about half of the 12.3 percentage point contribution of non-standard legal rates to the difference between VRR and CR.

The proportion of services that attract the 5\% VAT rates is relatively small, at about $8 \%$ of service sales to final consumption. Concessional VAT rates on services explain about -0.2 percentage points of the column 2 result for AVELRTOT. This accounts for just under one sixth of the 12.3 percentage point contribution of nonstandard legal rates to the difference between VRR and CR.

\subsection{Legal exemptions}

In column 1 of Table 3, values for $\mathrm{LEX}_{\mathrm{c}, \mathrm{s}, \mathrm{u}}$ are set at their VRR-implicit rate of 0 . Column 3 reports the effects of moving $\operatorname{LEX}_{c, s, u}$ to their true values. This raises the value of the average legal exemption rate (AVELEXTOT) by 0.26. 
Inspecting the results across row 4 of Table 3, we see that legal exemptions account for about two thirds of the value of Vietnam's average effective exemption rate.

Legal VAT exemptions have two opposing effects. On the one hand, they reduce the VAT final consumption and investment base, because households, government and investors do not have to pay VAT on exempt commodities (rows 5b - 5c, column 3). On the other hand, they expand the tax base on inputs to production, because producers of exempt goods can no longer claim VAT paid on inputs used to produce those goods (row 5a, column 3). For Vietnam, the first effect is larger than the second. With education, health care, water, dwellings, and parts of many other services exempt, the theoretical VAT base of final consumption is reduced by over 20\%. The theoretical VAT base on intermediate inputs increases from 0 to about $12 \%$ of the total final VAT base. The combined effect is a reduction in the theoretical base of $9 \%(=-55.4 / 621.8 * 100)$. This causes CR to rise by 7.7 percentage points.

\subsection{Non-registration for VAT purposes}

Column 4, Table 2 reports the effects of introducing non-registration for VAT purposes. This proves a relatively unimportant part of Vietnam's VAT compliance story, explaining only -2 percentage points of the gap between Vietnam's VRR and CR index values (row 8, column 4).

The direct effect of the introduction of VAT non-registration is to change the effective exemption rates (see equation E13). As discussed in Section 4.3, nonregistration rates are non-zero for most industries, and very high in agriculture and certain services, such as trade, restaurants, and miscellaneous services. The de facto exemption rates due to non-registration exceed the legislated exemption rates for most commodities. Overall, the average effective exemption rate is increased by 9.5 percentage points (row 4, column 4, Table 3). The increase in effective exemption 
rates has two opposing effects: while increasing the VAT base for intermediate inputs, it decreases the final consumption VAT base. The intermediate input and investment VAT bases expand by just over VND 165 tr (rows 5a and 5b, column 4), because of the increase in effective exemption rates for agriculture and manufacturing. The final consumption VAT base falls (row 5c) because effective exemptions increase on agricultural and manufacturing commodity sales. Important components of final consumption, such as education, health care and public administration are already fully exempted in column 3. Non-registration rates in these industries are small, and thus effective exemption rates for the commodities produced by these industries are unchanged. Overall, accounting for non-registration causes a small net expansion in the aggregate theoretical VAT base (row 5, column 4). This generates a small net expansion in theoretical VAT liabilities (row 6, column 4), making a negative contribution to the VRR - CR gap (row 8).

\subsection{VAT refund exclusions on selected inputs to capital formation}

Column 5, Table 3 reports the effects of VAT refund exclusions on certain inputs to capital formation in the health, education, defense and dwellings sectors. These exclusions expand the VAT theoretical base by VND 21 trillion (row 5, column 5, Table 3). Non-refundability of VAT on inputs to dwellings construction alone increases the theoretical base by approximately VND 20 trillion. The remaining increase in the VAT theoretical base (VND 1 trillion) is due to VAT refund exclusions on selected inputs to capital formation in the health, education and defense sectors. The increase in the theoretical base causes theoretical VAT liabilities to rise (row 6, column 5), reducing the gap between the VRR and CR indexes (row 8, column 5). 


\subsection{VAT on domestic non-resident purchases}

Column 6, Table 3 reports the effects of levying VAT on domestic purchases by non-residents. Spending by foreigners visiting Vietnam for tourism, conferences and business is an important part of Vietnam's export income. In 2005, expenditure by foreign visitors was approximately VND 46 trillion, which comprised about 8\% of total exports, or 5.5\% of GDP (GSO 2006c). Major items of expenditure by foreign visitors include hotels, food, transport, shopping, and services. When purchasing these commodities, foreign visitors face the same VAT rates and effective exemptions as Vietnamese households. Vietnam does not have a VAT refund scheme for domestic non-resident purchases ${ }^{26}$. Our VAT model estimates total VAT liabilities on domestic purchases by non-residents (TVATEXP) at VND 3.8 trillion (row $6 \mathrm{~b}$, column 7 , Table 3 ). This accounts for -0.046 of the gap between the VRR and CR measures (row 8, column 6).

\section{CONCLUDING REMARKS}

This paper presents a formal and comprehensive framework for modelling VAT. Our VAT system incorporates details of both VAT tax code and the economic structure on which VAT is applied. To our knowledge, this system is among the most detailed and clearly specified frameworks for VAT modelling in the VAT literature. The framework is easy to apply to any country with national accounts, government finance and input-output data. ${ }^{27}$ In this paper, we employ the system as a means of

\footnotetext{
${ }^{26}$ Vietnam began considering such a scheme in 2009, as a means of promoting tourism (Vietnamese Communist Party, 2010).

${ }^{27}$ National accounts and input-output data for many countries are available from the GTAP database. The GTAP 7.1 database, for example, contains input-output data for more than 90 countries (Source: https://www.gtap.agecon.purdue.edu/databases/regions.asp?Version=7.312).
} 
calculating a more informative index of average tax compliance (CR) than such commonly used measures as CE, VP and VRR. However, our system not only calculates an economy-wide average compliance rate, but data permitting, also provides for estimation of compliance rates at a highly disaggregate level, namely by commodity, source, and user. This more detailed compliance rate information could be of value to tax authorities in identifying problem areas and targeting their enforcement efforts more effectively.

We apply our VAT system to the case of Vietnam. Our calculations show that the compliance rate in Vietnam in 2005 was 85\%. This is much higher than the $71 \%$ implied by the crude CE index. A well known limitation of the CE index is that it does not account for many of the characteristics of real world VAT systems. In the case of Vietnam, these features include differential VAT rates, many exemptions, non-registration of businesses in the informal sector, and numerous legislated limits on investment input credits. Naturally, like all applied work, our CR calculations for Vietnam are subject to a number of caveats. By nature, the informal sector is difficult to measure. However, a strength of our system is that by defining variables like REG and IM, assumptions about the extent of informality in production and imports are made explicit.

Our VAT framework facilitates a decomposition of the gap between the CE and CR index values. In the case of Vietnam, much of this gap is due to the proliferation of both non-standard VAT rates and legal exemptions. Non-registration of businesses for VAT purposes, and limits on VAT credit for investment, contribute relatively little to the gap between the CE and CR measures. This suggests that raising legal rates and removing or reducing legislated exemptions might be an effective way of raising VAT revenue. This possibility could be explored more 
rigorously by embedding our VAT system within a larger economy-wide model, such as a CGE model. For example, Giesecke and Tran (2010) embed a much smaller example of such a system within a large-scale CGE model to explore the consequences of equalisation of VAT rates at a single revenue-neutral rate. With (E1) - (E17) embedded in a CGE model, a number of variables that are presently exogenous (in particular, BASIC, M, SO, SJ, SS and VAT) would become endogenous. The initial value of FCR would be set exogenously at a value that ensured that (E1)-(E17) produced a value for VATTOT that conformed with government finance statistics. With (E1)-(E17) embedded in a CGE model, many interesting simulations become possible. These would include exploring the economy-wide and distributional effects of moving to higher compliance rates, and exploring the consequences of higher registration rates as the economy develops. 
Figure 1. Equations of the VAT model

\section{The core VAT model}

(E1) $\quad \operatorname{VAT}_{\mathrm{c}, \mathrm{s}, \mathrm{u}}=\mathrm{CRT}_{\mathrm{c}, \mathrm{s, \textrm {u }}} \times \mathrm{TBASE}_{\mathrm{c}, \mathrm{s}, \mathrm{u}} \times \mathrm{LR}_{\mathrm{c}, \mathrm{s}, \mathrm{u}}$

$(c \in M, s \in S, u \in V)$

(E2) $\quad$ VATTOT $=\sum_{\mathrm{c} \in \mathrm{M}} \sum_{\mathrm{s} \in \mathrm{S}} \sum_{\mathrm{u} \in \mathrm{U}} \mathrm{VAT}_{\mathrm{c}, \mathrm{s}, \mathrm{u}}$

(E3) $\quad$ CR $=$ VATTOT $/$ TVATTOT

(E4) $\quad$ TVATTOT $=$ TVATDOM + TVATEXP

(E5) TVATDOM $=\sum_{\mathrm{c} \in \mathrm{M}} \sum_{\mathrm{s} \in \mathrm{S}} \sum_{\mathrm{u} \in \mathrm{D}}\left(\mathrm{TBASE}_{\mathrm{c}, \mathrm{su}} \times \mathrm{LR}_{\mathrm{c}, \mathrm{su}}\right)$

(E6) $\quad$ TVATEXP $=-$ NRESREF +

$\sum_{\mathrm{c} \in \mathrm{M}} \sum_{\mathrm{s} \in \mathrm{S}}\left[\operatorname{VBASE}_{\mathrm{c}, \mathrm{sexport}} \times\left(1-\mathrm{EX}_{\mathrm{c}, \mathrm{s} \text { export }}\right) \times \mathrm{SHNRES}_{\mathrm{c}, \mathrm{s}}\right] \times \mathrm{D} \times \mathrm{LR}_{\mathrm{c}, \text {,household }}+$ $\sum_{\mathrm{c} \in \mathrm{M}} \sum_{\mathrm{s} \in \mathrm{S}}\left[\operatorname{VBASE}_{\mathrm{c}, \mathrm{s} \text { export }} \times\left(1-\mathrm{EX}_{\mathrm{c}, \mathrm{s}, \mathrm{export}}\right) \times\left(1-\mathrm{SHNRES}_{\mathrm{c}, \mathrm{s}}\right)\right] \times \mathrm{D} \times \mathrm{LR}_{\mathrm{c}, \mathrm{s}, \mathrm{export}}$

(E7) $\quad$ VBASE $_{c, s, u}=$ BASIC $_{c, s, u} \times\left(1+T_{c, s, u}\right) \times\left(1+\mathrm{M}_{c, s, u}\right)$

$(c \in M, s \in S, u \in U)$

(E8) $\quad$ TBASE $_{\mathrm{c}, \mathrm{s}, \mathrm{f}}=\mathrm{VBASE}_{\mathrm{c}, \mathrm{s}, \mathrm{f}} \times\left[1-\mathrm{EX}_{\mathrm{c}, \mathrm{s}, \mathrm{f}}\right]$

$(c \in M, s \in S, f \in D)$

(E9) $\quad$ TBASE $_{\mathrm{c}, \mathrm{s}, \mathrm{j}}=\operatorname{VBASE}_{\mathrm{c}, \mathrm{j}, \mathrm{j}} \times\left[1-\mathrm{EX}_{\mathrm{c}, \mathrm{s}, \mathrm{j}}\right]\left[1-\phi_{j}^{(1)}\right]$

$(c \in M, s \in S, j \in N)$

(E10) $\quad$ TBASE $_{c, s, \mathrm{k}}=\operatorname{VBASE}_{c, s, \mathrm{k}} \times\left[1-\mathrm{EX}_{c, s, \mathrm{k}}\right]\left[1-\phi_{c, s, \mathrm{k}}^{(2)}\right]$

$(c \in M, s \in S, k \in K)$

(E11)

$\phi_{j}^{(1)}=\mathrm{REG}_{\mathrm{j}} \times \sum_{\mathrm{c} \in \mathrm{M}} \mathrm{SO}_{\mathrm{c}, \mathrm{j}} \sum_{\mathrm{u} \in \mathrm{U}} \mathrm{SS}_{\mathrm{c}, \mathrm{u}}\left[1-\mathrm{LEX}_{\mathrm{c}, \mathrm{dom}, \mathrm{u}}\right]$

$(j \in N)$

(E12) $\quad \mathrm{REG}_{\mathrm{j}}=\left(1-\mathrm{NRI}_{\mathrm{j}}\right)\left(1-\mathrm{NRL}_{\mathrm{j}}\right)$

$(j \in N)$

(E13) $\quad \operatorname{EX}_{c, s, u}=\operatorname{MAX}\left[\operatorname{LEX}_{c, s, u}, \operatorname{DEX}_{c, s}\right]$

$(c \in M, s \in S, u \in U)$

(E14) $\quad \mathrm{DEX}_{\mathrm{c}, \text { Domestic }}=1-\sum_{\mathrm{j} \in \mathrm{N}} \mathrm{SJ}_{\mathrm{c}, \mathrm{j}} \mathrm{REG}_{\mathrm{j}}$

$(c \in M)$

(E15) $\quad \mathrm{DEX}_{\mathrm{c}, \mathrm{Import}}=\mathrm{IM}_{\mathrm{c}}$

$(c \in M)$

(E16) $\quad \phi_{c, s, k}^{(2)}=\psi_{c, s, k} \times \mathrm{REG}_{\mathrm{k}}$

$(c \in M, s \in S, k \in K$ 
(E17) $\quad \mathrm{CRT}_{\mathrm{c}, \mathrm{s}, \mathrm{u}}=\mathrm{FCRT}_{\mathrm{c}, \mathrm{su}} \times \mathrm{FCR}$

$(c \in M, s \in S, u \in U)$

\section{Equations for summary variables reported in Table 1}

(E18) $\quad$ AVELR $_{\text {Producers }}=$

$\sum_{\mathrm{c} \in \mathrm{M}} \sum_{\mathrm{s} \in S} \sum_{j \in N}\left(\operatorname{TBASE}_{\mathrm{c}, \mathrm{j}, \mathrm{j}} \times \mathrm{LR}_{\mathrm{c}, \mathrm{s}, \mathrm{j}}\right) / \sum_{\mathrm{c} \in \mathrm{M}} \sum_{\mathrm{s} \in S} \sum_{j \in N} \operatorname{TBASE}_{\mathrm{c}, \mathrm{s}, \mathrm{j}}$

(E19) $\quad$ AVELR $_{\text {Investors }}=$

$\sum_{\mathrm{c} \in \mathrm{M}} \sum_{\mathrm{s} \in S} \sum_{k \in K}\left(\right.$ TBASE $\left._{\mathrm{c}, \mathrm{s}, \mathrm{k}} \times \mathrm{LR}_{\mathrm{c}, \mathrm{s}, \mathrm{k}}\right) / \sum_{\mathrm{c} \in \mathrm{M}} \sum_{\mathrm{s} \in S} \sum_{k \in K}$ TBASE $_{\mathrm{c}, \mathrm{s}, \mathrm{k}}$

(E20) $\quad \operatorname{AVELR}_{\mathrm{f}}=\sum_{\mathrm{c} \in \mathrm{M}} \sum_{\mathrm{s} \in S}\left(\mathrm{TBASE}_{\mathrm{c}, \mathrm{f}, \mathrm{f}} \times \mathrm{LR}_{\mathrm{c}, \mathrm{s}, \mathrm{f}}\right) / \sum_{\mathrm{c} \in \mathrm{M}} \sum_{\mathrm{s} \in S} \mathrm{TBASE}_{\mathrm{c}, \mathrm{f}, \mathrm{f}}$

(E21) AVELEX $X_{\text {Producers }}=$

$\sum_{\mathrm{c} \in \mathrm{M}} \sum_{\mathrm{s} \in S} \sum_{j \in N}\left(\operatorname{VBASE}_{\mathrm{c}, \mathrm{j}, \mathrm{L}} \times \operatorname{LEX}_{\mathrm{c}, \mathrm{s}, \mathrm{j}}\right) / \sum_{\mathrm{c} \in \mathrm{M}} \sum_{\mathrm{s} \in S} \sum_{j \in N} \operatorname{VBASE}_{\mathrm{c}, \mathrm{s}, \mathrm{j}}$

(E22) $\quad$ AVELEX $_{\text {Investors }}=$

$\sum_{\mathrm{c} \in \mathrm{M}} \sum_{\mathrm{s} \in \mathrm{S}} \sum_{k \in K}\left(\operatorname{VBASE}_{\mathrm{c}, \mathrm{s}, \mathrm{k}} \times \operatorname{LEX}_{\mathrm{c}, \mathrm{s}, \mathrm{k}}\right) / \sum_{\mathrm{c} \in \mathrm{M}} \sum_{\mathrm{s} \in \mathrm{S}} \sum_{k \in K} \operatorname{VBASE}_{\mathrm{c}, \mathrm{s}, \mathrm{k}}$

$\operatorname{AVELEX}_{\mathrm{f}}=\sum_{\mathrm{c} \in \mathrm{M}} \sum_{\mathrm{s} \in \mathrm{S}}\left(\operatorname{VBASE}_{\mathrm{c}, \mathrm{s}, \mathrm{f}} \times \operatorname{LEX}_{\mathrm{c}, \mathrm{s}, \mathrm{f}}\right) / \sum_{\mathrm{c} \in \mathrm{M}} \sum_{\mathrm{s} \in \mathrm{S}} \operatorname{VBASE}_{\mathrm{c}, \mathrm{s}, \mathrm{f}}$

$\operatorname{AVEDEX}_{\text {Producers }}=$

$\sum_{\mathrm{c} \in \mathrm{M}} \sum_{\mathrm{s} \in S} \sum_{j \in N}\left(\operatorname{VBASE}_{\mathrm{c}, \mathrm{j}, \mathrm{j}} \times \operatorname{DEX}_{\mathrm{c}, \mathrm{s}}\right) / \sum_{\mathrm{c} \in \mathrm{M}} \sum_{\mathrm{s} \in S} \sum_{j \in N} \operatorname{VBASE}_{\mathrm{c}, \mathrm{s}, \mathrm{j}}$

(E25) $\quad$ AVEDEX $_{\text {Investors }}=$

$\sum_{\mathrm{c} \in \mathrm{M}} \sum_{\mathrm{s} \in \mathrm{S}} \sum_{k \in K}\left(\operatorname{VBASE}_{\mathrm{c}, \mathrm{s}, \mathrm{k}} \times \mathrm{DEX}_{\mathrm{c}, \mathrm{s}}\right) / \sum_{\mathrm{c} \in \mathrm{M}} \sum_{\mathrm{s} \in \mathrm{S}} \sum_{k \in K} \operatorname{VBASE}_{\mathrm{c}, \mathrm{s}, \mathrm{k}}$

(E26) $\quad \operatorname{AVEDEX}_{\mathrm{f}}=\sum_{\mathrm{c} \in \mathrm{M}} \sum_{\mathrm{s} \in \mathrm{S}}\left(\operatorname{VBASE}_{\mathrm{c}, \mathrm{s}, \mathrm{f}} \times \operatorname{DEX}_{\mathrm{c}, \mathrm{s}}\right) / \sum_{\mathrm{c} \in \mathrm{M}} \sum_{\mathrm{s} \in \mathrm{S}} \operatorname{VBASE}_{\mathrm{c}, \mathrm{s}, \mathrm{f}}$

$(f \in \mathrm{D})$

(E27) $\quad$ AVEEX $\mathrm{P}_{\text {Producers }}=$

$\sum_{\mathrm{c} \in \mathrm{M}} \sum_{\mathrm{s} \in \mathrm{S}} \sum_{j \in N}\left(\operatorname{VBASE}_{\mathrm{c}, \mathrm{s}, \mathrm{j}} \times \mathrm{EX}_{\mathrm{c}, \mathrm{s,j}}\right) / \sum_{\mathrm{c} \in \mathrm{M}} \sum_{\mathrm{s} \in \mathrm{S}} \sum_{j \in N} \operatorname{VBASE}_{\mathrm{c}, \mathrm{s}, \mathrm{j}}$

(E28) $\quad$ AVEEX $_{\text {Investors }}=$

$\sum_{\mathrm{c} \in \mathrm{M}} \sum_{\mathrm{s} \in S} \sum_{k \in K}\left(\operatorname{VBASE}_{\mathrm{c}, \mathrm{s}, \mathrm{k}} \times \mathrm{EX}_{\mathrm{c}, \mathrm{s}, \mathrm{k}}\right) / \sum_{\mathrm{c} \in \mathrm{M}} \sum_{\mathrm{s} \in S} \sum_{k \in K} \operatorname{VBASE}_{\mathrm{c}, \mathrm{s}, \mathrm{k}}$

(E29) $\quad \operatorname{AVEEX}_{\mathrm{f}}=\sum_{\mathrm{c} \in \mathrm{M}} \sum_{\mathrm{s} \in \mathrm{S}}\left(\mathrm{VBASE}_{\mathrm{c}, \mathrm{f}, \mathrm{f}} \times \mathrm{EX}_{\mathrm{c}, \mathrm{s}, \mathrm{f}}\right) / \sum_{\mathrm{c} \in \mathrm{M}} \sum_{\mathrm{s} \in \mathrm{S}} \operatorname{VBASE}_{\mathrm{c}, \mathrm{f}, \mathrm{f}}$

$(f \in \mathrm{D})$

(E30) AVEREF1 $=\sum_{\mathrm{c} \in \mathrm{M}} \sum_{\mathrm{s} \in S} \sum_{j \in N}\left(\mathrm{VBASE}_{\mathrm{c}, \mathrm{j}, \mathrm{j}} \times \phi_{j}^{(1)}\right) / \sum_{\mathrm{c} \in \mathrm{M}} \sum_{\mathrm{s} \in \mathrm{S}} \sum_{j \in N} \operatorname{VBASE}_{\mathrm{c}, \mathrm{s}, \mathrm{j}}$ 
(E31) AVEREF2 $=\sum_{\mathrm{c} \in \mathrm{M}} \sum_{\mathrm{s} \in \mathrm{S}} \sum_{k \in K}\left(\operatorname{VBASE}_{\mathrm{c}, \mathrm{s}, \mathrm{k}} \times \phi_{\mathrm{c}, \mathrm{s}, \mathrm{k}}^{(2)}\right) / \sum_{\mathrm{c} \in \mathrm{M}} \sum_{\mathrm{s} \in \mathrm{S}} \sum_{k \in K} \operatorname{VBASE}_{\mathrm{c}, \mathrm{s}, \mathrm{k}}$

(E32) $\quad$ TBASE $_{\text {Producers }}=\sum_{\mathrm{c} \in \mathrm{M}} \sum_{\mathrm{s} \in S} \sum_{j \in N} \mathrm{TBASE}_{\mathrm{c}, \mathrm{s}, \mathrm{j}}$

(E33) $\quad$ TBASE $_{\text {Investors }}=\sum_{\mathrm{c} \in \mathrm{M}} \sum_{\mathrm{s} \in S} \sum_{k \in K} \mathrm{TBASE}_{\mathrm{c}, \mathrm{s}, \mathrm{k}}$

(E34) $\quad$ TBASE $_{\mathrm{f}}=\sum_{\mathrm{c} \in \mathrm{M}} \sum_{\mathrm{s} \in S} \operatorname{TBASE}_{\mathrm{c}, \mathrm{f}, \mathrm{f}}$

(E35) $\quad \operatorname{TVAT}_{\text {Producers }}=\sum_{\mathrm{c} \in \mathrm{M}} \sum_{\mathrm{s} \in S} \sum_{j \in N}\left(\mathrm{TBASE}_{\mathrm{c}, \mathrm{s}, \mathrm{j}} \times \mathrm{LR}_{\mathrm{c}, \mathrm{s}, \mathrm{j}}\right)$

(E36) $\quad \operatorname{TVAT}_{\text {Investors }}=\sum_{\mathrm{c} \in \mathrm{M}} \sum_{\mathrm{s} \in S} \sum_{k \in K}\left(\mathrm{TBASE}_{\mathrm{c}, \mathrm{s}, \mathrm{k}} \times \mathrm{LR}_{\mathrm{c}, \mathrm{s}, \mathrm{k}}\right)$

(E37) $\quad \operatorname{TVAT}_{\mathrm{f}}=\sum_{\mathrm{c} \in \mathrm{M}} \sum_{\mathrm{s} \in S}\left(\mathrm{TBASE}_{\mathrm{c}, \mathrm{f}, \mathrm{f}} \times \mathrm{LR}_{\mathrm{c}, \mathrm{s}, \mathrm{f}}\right)$

\section{Equations for summary variables reported in Table 3}

(E38) AVELRTOT $=$ $\sum_{\mathrm{c} \in \mathrm{M}} \sum_{\mathrm{s} \in \mathrm{S}} \sum_{\mathrm{u} \in \mathrm{V}}\left(\mathrm{TBASE}_{\mathrm{c}, \mathrm{s}, \mathrm{u}} \times \mathrm{LR}_{\mathrm{c}, \mathrm{s}, \mathrm{u}}\right) / \sum_{\mathrm{c} \in \mathrm{M}} \sum_{\mathrm{s} \in \mathrm{S}} \sum_{\mathrm{u} \in \mathrm{V}} \operatorname{TBASE}_{\mathrm{c}, \mathrm{s}, \mathrm{u}}$

(E39) AVEDEXTOT= $\sum_{\mathrm{c} \in \mathrm{M}} \sum_{\mathrm{s} \in \mathrm{S}} \sum_{\mathrm{u} \in \mathrm{V}}\left(\operatorname{VBASE}_{\mathrm{c}, \mathrm{s}, \mathrm{u}} \times \mathrm{DEX}_{\mathrm{c}, \mathrm{su}}\right) / \sum_{\mathrm{c} \in \mathrm{M}} \sum_{\mathrm{s} \in \mathrm{S}} \sum_{\mathrm{u} \in \mathrm{V}} \operatorname{VBASE}_{\mathrm{c}, \mathrm{s}, \mathrm{u}}$

(E40) AVEEXTOT $=$ $\sum_{\mathrm{c} \in \mathrm{M}} \sum_{\mathrm{s} \in \mathrm{S}} \sum_{\mathrm{u} \in \mathrm{V}}\left(\operatorname{VBASE}_{\mathrm{c}, \mathrm{su}} \times \mathrm{EX}_{\mathrm{c}, \mathrm{s,u}}\right) / \sum_{\mathrm{c} \in \mathrm{M}} \sum_{\mathrm{s} \in S} \sum_{\mathrm{u} \in \mathrm{V}} \operatorname{VBASE}_{\mathrm{c}, \mathrm{s}, \mathrm{u}}$

(E41) TBASETOT1 $=\sum_{\mathrm{c} \in \mathrm{M}} \sum_{\mathrm{s} \in \mathrm{S}} \sum_{\mathrm{j} \in \mathrm{N}} \mathrm{TBASE}_{\mathrm{c}, \mathrm{j}, \mathrm{j}}$

(E42) $\quad$ TBASETOT2 $=\sum_{\mathrm{c} \in \mathrm{M}} \sum_{\mathrm{s} \in \mathrm{S}} \sum_{\mathrm{k} \in \mathrm{K}} \mathrm{TBASE}_{\mathrm{c}, \mathrm{s}, \mathrm{k}}$

(E43) $\quad$ TBASETOT35 $=\sum_{\mathrm{c} \in \mathrm{M}} \sum_{\mathrm{s} \in \mathrm{S}}$ TBASE $_{\mathrm{c}, \mathrm{S}, \text { Households }}+\sum_{\mathrm{c} \in \mathrm{M}} \sum_{\mathrm{s} \in \mathrm{S}}$ TBASE $_{\mathrm{c}, \mathrm{S}, \text { Government }}$

(E44) $\quad$ TBASETOT $=$ TBASETO1+TBASETOT2+TBASETOT35 
SETS

\begin{tabular}{|l|l|l|}
\hline Set name & Set elements & Description \\
\hline $\mathrm{M}$ & $(\mathrm{c}=1, \ldots, \mathrm{m})$ & Set of all commodities. \\
\hline $\mathrm{S}$ & $(\mathrm{s}=$ domestic, imported) & $\begin{array}{l}\text { Set of all commodity } \\
\text { sources. }\end{array}$ \\
\hline $\mathrm{N}$ & $(\mathrm{j}=1, \ldots, n)$ & Set of all producers. \\
\hline $\mathrm{K}$ & $(\mathrm{k}=1, \ldots, k)$ & Set of all investors. \\
\hline $\mathrm{F}$ & $($ households, export, government, stocks) & Set of all final purchasers. \\
\hline $\mathrm{D}$ & $($ households, government, stocks) & $\begin{array}{l}\text { Set of all domestic final } \\
\text { purchasers. }\end{array}$ \\
\hline $\mathrm{U}$ & $(\mathrm{N} \cup \mathrm{K} \cup \mathrm{F})$ & Set of all purchasers. \\
\hline $\mathrm{V}$ & $\begin{array}{l}\text { ( N } \cup \mathrm{K} \cup \mathrm{D}) \\
\text { Set of all domestic } \\
\text { purchasers }\end{array}$ \\
\hline $\mathrm{Q}$ & $\begin{array}{l}\text { (Producers, investors, households, } \\
\text { government, stocks) }\end{array}$ & $\begin{array}{l}\text { Set of major domestic } \\
\text { agents. }\end{array}$ \\
\hline
\end{tabular}


Figure 2. Variables and parameters of the model, in alphabetical order

(a) Variables and parameter in the core model (Equations E1 - E17)

\begin{tabular}{|c|c|c|c|c|}
\hline & Variable & Range & Description & Closure \\
\hline 1 & BASIC $_{\mathrm{c}, \mathrm{su}}$ & $\begin{array}{l}(c \in \mathrm{M}) \\
(s \in S) \\
(u \in \mathrm{U})\end{array}$ & $\begin{array}{l}\text { Value, at basic prices, of purchases by user } u \\
\text { of commodity } c \text { from } s \text {. }\end{array}$ & Ex. $^{\mathrm{a}}$ \\
\hline 2 & $\mathrm{CRT}_{\mathrm{c}, \mathrm{su}}$ & $\begin{array}{l}(c \in \mathrm{M}) \\
(s \in S) \\
(u \in \mathrm{U})\end{array}$ & Transaction-specific compliance rates. & En. \\
\hline 3 & CR & & $\begin{array}{l}\text { Average economy-wide VAT compliance } \\
\text { rate. }\end{array}$ & En. \\
\hline 4 & $\mathrm{DEX}_{\mathrm{c}, \mathrm{domestic}}$ & $(c \in \mathrm{M})$ & $\begin{array}{l}\text { De-factor exemption: the proportion of sales } \\
\text { of domestically-produced commodity } c \text { that } \\
\text { are effectively VAT exempt due to non- } \\
\text { registration by producers of } c \text {. }\end{array}$ & En. \\
\hline 5 & $\operatorname{DEX}_{\text {c,import }}$ & $(c \in \mathrm{M})$ & $\begin{array}{l}\text { De-factor exemption: the proportion of sales } \\
\text { of imported commodity c that are effectively } \\
\text { VAT exempt due to undeclared imports. }\end{array}$ & En. \\
\hline 6 & $\mathrm{EX}_{\mathrm{c}, \mathrm{s}, \mathrm{u}}$ & $\begin{array}{l}(c \in \mathrm{M}) \\
(s \in S) \\
(u \in \mathrm{U})\end{array}$ & $\begin{array}{l}\text { The proportion of sales of commodity } c \text { from } \\
\text { source } s \text { to user } u \text { that are effectively VAT } \\
\text { exempt. }\end{array}$ & En. \\
\hline 7 & FCR & & $\begin{array}{l}\text { Uniform shifter on transaction-specific } \\
\text { compliance rates. }\end{array}$ & En. \\
\hline 8 & FCRT $_{c, s, \mathrm{u}}$ & $\begin{array}{l}(c \in \mathrm{M}) \\
(s \in S) \\
(u \in \mathrm{U})\end{array}$ & $\begin{array}{l}\text { Shifter on transaction-specific compliance } \\
\text { rates. }\end{array}$ & Ex. $^{b}$ \\
\hline 9 & $\mathrm{IM}_{\mathrm{c}}$ & $(c \in M)$ & $\begin{array}{l}\text { The proportion of imports that is not declared } \\
\text { for tax purposes. }\end{array}$ & Ex. ${ }^{\mathrm{c}}$ \\
\hline 10 & $\operatorname{LEX}_{\mathrm{c}, \mathrm{su}}$ & $\begin{array}{l}(c \in \mathrm{M}) \\
(s \in S) \\
(u \in \mathrm{U})\end{array}$ & $\begin{array}{l}\text { The proportion of sales of commodity } c \text { from } \\
\text { source } s \text { to user } u \text { that are legally VAT } \\
\text { exempt. }\end{array}$ & Ex. $^{\mathrm{d}}$ \\
\hline 11 & $\mathrm{LR}_{\mathrm{c}, \mathrm{s}, \mathrm{u}}$ & $\begin{array}{l}(c \in \mathrm{M}) \\
(s \in S) \\
(u \in \mathrm{U})\end{array}$ & $\begin{array}{l}\text { The legal VAT rate on purchases of } \\
\text { commodity } c \text {, from source } s \text { by user } u \text {. }\end{array}$ & Ex. $^{e}$ \\
\hline 12 & $\psi_{c, s, k}$ & $\begin{array}{l}(c \in \mathrm{M}) \\
(s \in S) \\
(\mathrm{k} \in \mathrm{K})\end{array}$ & $\begin{array}{l}\text { The legal refund rate for VAT paid on inputs } \\
\text { of }(c, s) \text { to capital formation by industry } k \text {. }\end{array}$ & Ex. $^{f}$ \\
\hline 13 & $\mathrm{M}_{\mathrm{c}, \mathrm{su}}$ & $\begin{array}{l}c \in \mathrm{M}) \\
(s \in S) \\
(u \in \mathrm{U})\end{array}$ & $\begin{array}{l}\text { The value of margin services on flows of } \\
\text { commodity }(c, s) \text { to user } u \text {, expressed as a } \\
\text { proportion of the basic value of flows of }(c, s) \\
\text { to user } u \text {. }\end{array}$ & Ex. $^{\mathrm{g}}$ \\
\hline 14 & $\mathrm{NRI}_{\mathrm{j}}$ & $(j \in N)$ & $\begin{array}{l}\text { The proportion of industry j's activity } \\
\text { generated by firms which operate informally } \\
\text { and are thus not registered for VAT. }\end{array}$ & Ex. $^{\text {h }}$ \\
\hline 15 & $\mathrm{NRL}_{\mathrm{j}}$ & $(j \in N)$ & $\begin{array}{l}\text { The proportion of industry } j \text { 's output } \\
\text { produced by firms that are legally permitted } \\
\text { not to register for VAT. }\end{array}$ & Ex. ${ }^{i}$ \\
\hline 16 & $\overline{\phi_{j}^{(1)}}$ & $(j \in N)$ & $\begin{array}{l}\text { The proportion of VAT paid on inputs to } \\
\text { current production by industry } j \text { that is } \\
\text { refunded by the tax authority. }\end{array}$ & En. \\
\hline 17 & $\phi_{c, s, k}^{(2)}$ & $\begin{array}{l}(c \in \mathrm{M}) \\
(s \in S) \\
(\mathrm{k} \in \mathrm{K})\end{array}$ & $\begin{array}{l}\text { The proportion of VAT paid on inputs of } \\
(c, s) \text { to capital formation by industry } k \text { that is } \\
\text { refunded by the tax authority. }\end{array}$ & En. \\
\hline 18 & $\mathrm{REG}_{\mathrm{j}}$ & $(j \in N)$ & The proportion of industry j’s production & En. \\
\hline
\end{tabular}




\begin{tabular}{|c|c|c|c|c|}
\hline & & & represented by firms registered for VAT. & \\
\hline 19 & $\mathrm{SO}_{\mathrm{c}, \mathrm{j}}$ & $\begin{array}{l}(c \in M) \\
(j \in N)\end{array}$ & $\begin{array}{l}\text { The share of total output of industry } j \\
\text { represented by commodity } c \text {. }\end{array}$ & Ex. $^{j}$ \\
\hline 20 & $\mathrm{SJ}_{\mathrm{c}, \mathrm{j}}$ & $\begin{array}{l}(c \in M) \\
(j \in N)\end{array}$ & $\begin{array}{l}\text { Industry j's share of total output of } \\
\text { commodity } c \text {. }\end{array}$ & Ex. $^{\mathrm{k}}$ \\
\hline 21 & $\mathrm{SS}_{\mathrm{c}, \mathrm{u}}$ & $\begin{array}{l}(c \in M) \\
(u \in U)\end{array}$ & $\begin{array}{l}\text { The share of total sales of commodity } c \text { sold } \\
\text { to user } u \text {. }\end{array}$ & Ex. \\
\hline 22 & $\mathrm{~T}_{\mathrm{c}, \mathrm{s,u}}$ & $\begin{array}{l}(c \in \mathrm{M}) \\
(s \in S) \\
(u \in \mathrm{U})\end{array}$ & $\begin{array}{l}\text { The rate of any indirect taxes that form part } \\
\text { of the VAT tax base under the relevant } \\
\text { jurisdictions tax code. }\end{array}$ & Ex. $^{\mathrm{m}}$ \\
\hline 23 & TBASE $_{c, s, u}$ & $\begin{array}{l}(c \in \mathrm{M}) \\
(s \in S) \\
(u \in \mathrm{U})\end{array}$ & $\begin{array}{l}\text { Theoretical base for VAT on purchases of } \\
\text { commodity } c \text {, from source } s \text { by user } u \text {. }\end{array}$ & En. \\
\hline 24 & NRESREF & & $\begin{array}{l}\text { VAT refunds on domestic purchases by non- } \\
\text { residents. }\end{array}$ & Ex. $^{n}$ \\
\hline 25 & SHNRES $_{\mathrm{c}, \mathrm{s}}$ & $\begin{array}{l}(c \in \mathrm{M}) \\
(s \in S)\end{array}$ & $\begin{array}{l}\text { Share of export sales of commodity c,s } \\
\text { representing domestic sales to non-resident } \\
\text { agents (such as tourists). }\end{array}$ & Ex. $^{0}$ \\
\hline 26 & TVATTOT & & $\begin{array}{l}\text { Total theoretical VAT liabilities (or potential } \\
\text { VAT revenue). }\end{array}$ & En. \\
\hline 27 & TVATDOM & & $\begin{array}{l}\text { Total theoretical VAT liabilities on sales to } \\
\text { domestic agents. }\end{array}$ & En. \\
\hline 28 & TVATEXP & & $\begin{array}{l}\text { Total theoretical VAT liabilities on sales to } \\
\text { foreign agents. }\end{array}$ & En. \\
\hline 29 & $\mathrm{VAT}_{\mathrm{c}, \mathrm{s}, \mathrm{u}}$ & $\begin{array}{l}(c \in \mathrm{M}) \\
(s \in S) \\
(u \in \mathrm{U})\end{array}$ & $\begin{array}{l}\text { Actual VAT collections from the sale of } \\
\text { commodity } c \text { from source } s \text { to user } u \text {. }\end{array}$ & En. \\
\hline 30 & VATTOT & & Actual total VAT collections. & Ex. $^{\mathrm{p}}$ \\
\hline 31 & VBASE $_{\mathrm{c}, \mathrm{s}, \mathrm{u}}$ & $\begin{array}{l}(c \in \mathrm{M}) \\
(s \in S) \\
(u \in \mathrm{U})\end{array}$ & $\begin{array}{l}\text { Value of the base, relating to purchases of } \\
\text { commodity } c \text { from source } s \text { by user } u \text {, on } \\
\text { which VAT is levied. (if there were no } \\
\text { exemptions). }\end{array}$ & En. \\
\hline
\end{tabular}

(b) Variables reported in Tables (1) and (3) (Equations E18 - E44)

\begin{tabular}{|l|l|l|l|c|}
\hline 32 & AVELR $_{\mathrm{q}}$ & $(\mathrm{q} \in \mathrm{Q})$ & $\begin{array}{l}\text { Weighted average legal rate faced by the } \\
\text { broad classes of economic agent in the set Q, } \\
\text { namely: producers, investors, households and } \\
\text { government. }\end{array}$ & En. \\
\hline 33 & AVELEX $_{\mathrm{q}}$ & $(\mathrm{q} \in \mathrm{Q})$ & $\begin{array}{l}\text { Weighted average legal exemption rates on } \\
\text { purchases by broad economic agents in the } \\
\text { set Q. }\end{array}$ & En. \\
\hline 34 & AVEDEX $_{\mathrm{q}}$ & $(\mathrm{q} \in \mathrm{Q})$ & $\begin{array}{l}\text { Weighted average de facto exemption rates } \\
\text { due to non-registration on all purchases by } \\
\text { broad economic agents defined by set Q. }\end{array}$ & En. \\
\hline 35 & AVEEX $_{\mathrm{q}}$ & $(\mathrm{q} \in \mathrm{Q})$ & $\begin{array}{l}\text { Weighted average effective exemption rates } \\
\text { on all purchases by broad economic agents in } \\
\text { set Q. }\end{array}$ & En. \\
\hline 36 & AVEREF1 & & Weighted average refund rates on all & En. \\
\hline
\end{tabular}

${ }^{28}$ For many jurisdictions, $\mathrm{T}_{\mathrm{c}, \mathrm{s}, \mathrm{u}}$ will be zero. However for Vietnam, the Special Consumption Tax, an indirect tax levied on consumption of certain goods deemed to be luxuries, forms part of the base subject to VAT under Vietnam's VAT law (National Assembly 2003). 


\begin{tabular}{|l|l|l|l|c|}
\hline & & & purchases by producers. & \\
\hline 37 & AVEREF2 & & $\begin{array}{l}\text { Weighted average refund rates on all inputs } \\
\text { to capital formation. }\end{array}$ & En. \\
\hline 38 & TBASE $_{\mathrm{q}}$ & $(\mathrm{q} \in \mathrm{Q})$ & $\begin{array}{l}\text { Theoretical VAT bases on purchases by } \\
\text { broad economic agents in set Q. }\end{array}$ & En. \\
\hline 39 & TVAT $_{\mathrm{q}}$ & $(\mathrm{q} \in \mathrm{Q})$ & $\begin{array}{l}\text { Theoretical VAT liabilities on purchases by } \\
\text { the broad set of agents defined by set Q. }\end{array}$ & En. \\
\hline 40 & AVELRTOT & & $\begin{array}{l}\text { Economy-wide average legal rates, weighted } \\
\text { by the theoretical VAT base }\end{array}$ & En. \\
\hline 41 & AVELEXTOT & & $\begin{array}{l}\text { Economy-wide average legal exemption } \\
\text { rates, weighted by the comprehensive VAT } \\
\text { base (i.e. the base if all transactions are } \\
\text { taxed). }\end{array}$ & En. \\
\hline 42 & AVEDEXTOT & $\begin{array}{l}\text { Economy-wide average de facto exemption } \\
\text { rates, weighted by the comprehensive VAT } \\
\text { base. }\end{array}$ & En. \\
\hline 43 & AVEEXTOT & & $\begin{array}{l}\text { Economy-wide average effective exemption } \\
\text { rates, weighted by the comprehensive VAT } \\
\text { base. }\end{array}$ & En. \\
\hline 44 & TBASETOT & & Aggregate theoretical VAT base. & En. \\
\hline 45 & TBASETOT1 & & $\begin{array}{l}\text { Aggregate value of the theoretical VAT base } \\
\text { for producers' purchases. }\end{array}$ & En. \\
\hline 46 & TBASETOT2 & $\begin{array}{l}\text { Aggregate value of the theoretical VAT base } \\
\text { for investors' purchases. }\end{array}$ & En. \\
\hline 47 & TBASETOT35 & $\begin{array}{l}\text { Aggregate value of the theoretical VAT base } \\
\text { for households' and government's purchases. }\end{array}$ & En. \\
\hline
\end{tabular}

Ex. denotes exogenous

En. denotes endogenous

a. $\quad$ Calculated from the basic price use table of the national input-output statistics.

b. $\quad$ Exogenous set at 1, when independent values for $\mathrm{VAT}_{\mathrm{c}, \mathrm{s}, \mathrm{u}}$ are unavailable.

c. Calculated from information on total imports and undeclared imports.

d. Calculated from inspection of the VAT legislation of the relevant country.

e. Calculated from inspection of the VAT legislation of the relevant country.

f. Calculated from inspection of the VAT legislation of the relevant country.

g. Calculated from margin values in the national input-output table.

h. Based on survey or other independent estimates of the number and size of enterprises in each industry that operate informally.

i. Based on survey or other independent estimates of the number and size of enterprises in each industry that are legally permitted to not register for VAT, and have chosen to do so.

j. $\quad$ Calculated from the supply table of the country's input-output statistics.

k. $\quad$ Calculated from the supply table of the country's input-output statistics.

l. Calculated from the basic price use table of the national input-output statistics.

m. Calculated from inspection of the national VAT legislation and the indirect tax matrices of the national input-output statistics.

n. Data from the taxation authority on VAT refunds paid out under schemes to refund VAT on purchases by non-residents (such as tourists) at home.

o. Calculated from national input-output table, and other relevant statistics such as tourism satellite accounts.

p. Data from the tax authority on actual VAT collections. 
Table 1. Summary measures of VAT rates and bases in Vietnam, 2005

\begin{tabular}{|c|c|c|c|c|c|c|c|}
\hline \multirow[t]{2}{*}{ Users } & 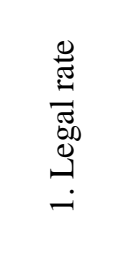 & 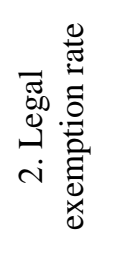 & 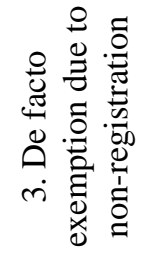 & 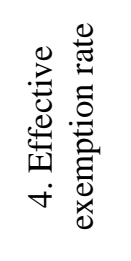 & 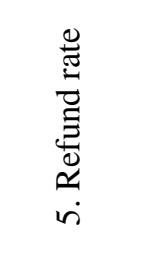 & 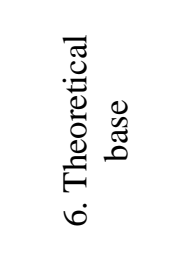 & \multirow{2}{*}{ 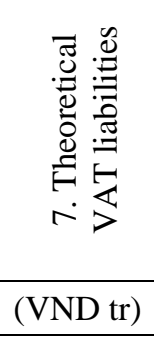 } \\
\hline & $(\%)$ & $(\%)$ & $(\%)$ & $(\%)$ & $(\%)$ & (VND tr) & \\
\hline$\underline{\text { Variable }}$ & AVELR & AVLEX & AVEDEX & AVEEX & AVEREF & TBASE & TVAT \\
\hline 1 Producers & 8.0 & 24.1 & 14.6 & 27.3 & 75.0 & 186.6 & 14.9 \\
\hline 2 Investors & 8.7 & 18.0 & 2.5 & 20.2 & 70.8 & 69.6 & 6.0 \\
\hline 3 Households & 8.7 & 20.4 & 27.9 & 33.9 & - & 337.1 & 29.3 \\
\hline 4 Government & 6.3 & 84.3 & 3.1 & 85.8 & - & 15.9 & 1.0 \\
\hline $\begin{array}{l}5 \text { Economy-wide } \\
\text { average or total }\end{array}$ & 8.4 & 25.7 & 15.7 & 31.4 & 74.1 & 609.1 & 51.3 \\
\hline \multicolumn{7}{|c|}{6 VAT collected on purchases by domestic non-residents } & 2.8 \\
\hline \multicolumn{7}{|c|}{7 Actual VAT revenue } & 45.9 \\
\hline \multicolumn{7}{|c|}{8 Compliance rate $(=7 /(5+6))$} & 0.85 \\
\hline
\end{tabular}

Table 2. Commodity composition of VAT bases (VBASE), aggregated across commodities and users (VND tr.)

\begin{tabular}{lrrrrr}
\hline Sector & 1.Production & 2.Investment & 3.Households & 4.Government & $\begin{array}{r}\text { 5.Whole } \\
\text { economy }\end{array}$ \\
\hline 1.Agriculture & 155.6 & 0.7 & 78.0 & 1.8 & 278.5 \\
2.Industry & 798.7 & 265.0 & 276.5 & 5.1 & 1821.2 \\
3.Services & 95.0 & 11.3 & 155.4 & 105.0 & 403.8 \\
\hline Total & 1049.3 & 277.0 & 509.9 & 111.9 & 2503.6 \\
\hline
\end{tabular}


Table 3. Decomposition of the VRR -CR gap for Vietnam

\begin{tabular}{|c|c|c|c|c|c|c|c|c|}
\hline & & & & & From VH & RR to CR & & \\
\hline Variable & & implicit & & Dec & omposition fa & actors & & \\
\hline & & $\begin{array}{c}\text { values for } \\
\text { exogenous } \\
\text { variables }\end{array}$ & $\begin{array}{c}\text { Legal VAT } \\
\text { rates }\end{array}$ & $\begin{array}{l}\text { Legal VAT } \\
\text { exemption } \\
\text { rates }\end{array}$ & $\begin{array}{l}\text { Non- } \\
\text { registration } \\
\text { for VAT } \\
\text { purposes } \\
\end{array}$ & $\begin{array}{l}\text { VAT refund } \\
\text { exclusions } \\
\text { on inputs to } \\
\text { investment }\end{array}$ & $\begin{array}{c}\text { VAT on } \\
\text { non-resident } \\
\text { purchases }\end{array}$ & $\begin{array}{c}\text { values for } \\
\text { exogenous } \\
\text { variables }\end{array}$ \\
\hline & & & $\mathrm{LR}_{\mathrm{c}, \mathrm{s}, \mathrm{u}}$ & $\operatorname{LEX}_{c, s, \mathrm{u}}$ & $\mathrm{NRI}_{\mathrm{j}}, \mathrm{NRL}_{\mathrm{j}}$ & $\psi_{\mathrm{c}, \mathrm{s}, \mathrm{k}}$ & D,NRESREF & \\
\hline Description & Name & $(1)$ & $(2)$ & (3) & $(4)$ & (5) & (6) & (7) \\
\hline 1.Legal rate & AVELRTOT & 0.10 & -0.015 & -0.001 & 0 & 0 & 0 & 0.084 \\
\hline 2.Average legal exemption rate & AVELEXTOT & 0 & 0 & 0.257 & 0 & 0 & 0 & 0.257 \\
\hline 3.Average de facto exemption rate & AVEDEXTOT & 0 & 0 & 0 & 0.157 & 0 & 0 & 0.157 \\
\hline 4.Effective exemption rate & AVEERTOT & 0 & 0 & 0.219 & 0.095 & 0 & 0 & 0.314 \\
\hline 5.Total theoretical base (VND tr.) & TBASETOT & 621.8 & 0 & -55.4 & 22.8 & 21.1 & 0 & 610.3 \\
\hline 5a.Theoretical base, intermediate & TBASETOT1 & 0.0 & 0 & 73.6 & 113.9 & 0 & 0 & 187.5 \\
\hline 5b.Theoretical base, investment & TBASETOT2 & 0.0 & 0 & -4.6 & 53.5 & 21.1 & 0 & 69 \\
\hline 5c.Theoretical base, final consumption & TBASETOT35 & 621.8 & 0 & -124 & -144 & 0 & 0 & 352.9 \\
\hline 6. Theoretical VAT liabilities (VND tr.) & & 62.18 & -9.9 & -5.9 & 1.9 & 2.1 & 3.8 & 54.13 \\
\hline 6a.Theoretical VAT liabilities, domestic & TVATDOM & 62.2 & -10 & -5 & 2 & 2 & 0 & 51.3 \\
\hline 6b.Theoretical VAT liabilities, exports & TVATEXP & 0.0 & -0.1 & -0.5 & -0.4 & 0.0 & 3.8 & 2.8 \\
\hline 7. Actual VAT revenue (VND tr.) & VATTOT & 45.9 & 0 & 0 & 0 & 0 & 0 & 45.9 \\
\hline 8. Index value ${ }^{f}$ & CR & 0.74 & 0.123 & 0.077 & -0.020 & -0.025 & -0.046 & 0.85 \\
\hline
\end{tabular}




\section{REFERENCES}

Agha, A. and J. Haughton (1996) Designing VAT Systems: Some Efficiency Considerations, Review of Economics and Statistics, 78, 303-308.

Aizenman, J. and Y. Jinjarak (2008) The Collection Efficiency of the Value Added Tax: Theory and International Evidence, Journal of International Trade and Economic Development, 17, 391-410.

Bird, R. M., Gendron, P.-P., (2007) The VAT in Developing and Transitional Countries, Cambridge University Press, Cambridge.

Cnossen, S. (1990) Taxing Value Added: The OECD Experience, International VAT Monitor, 5, 2-16.

de Mello, L. (2009) Avoiding the Value Added Tax: Theory and Cross-Country Evidence, Public Finance Review, 37, 27-46.

Ebrill, L., M., Keen, M., Bodin, J.-P., Summers, V.,(2001) The modern VAT, International Monetary Fund, Washington, D.C.

Gebauer, A., C. W. Nam, et al. (2007) Can Reform Models of Value Added Taxation Stop the VAT Evasion and Revenue Shortfalls in the EU?, Journal of Economic Policy Reform, 10, 1-13.

Gebauer, A. and R. Parsche (2003) Evasion of Value-Added Taxes in Europe: IFO Approach to Estimating the Evasion of Value-Added Taxes on the Basis of National Accounts Data (NAD), CESifo DICE Report 2, pp 40-44.

General Statistics Office (2005) The non-farm individual business establishment survey, General Statistics Office, Vietnam, Available at http://www.gso.gov.vn (accessed 5 August 2008).

General Statistics Office of Vietnam (2006a) Industrial output value at current prices by ownership, Available at http://www.gso.gov.vn (accessed 5 August 2008). 
General Statistics Office of Vietnam (2006b) Vietnam Household Living Standard Survey 2004, Available at http://www.gso.gov.vn (accessed 5 August 2008).

General Statistics Office of Vietnam (2006c) Tourism Expenditure Survey in 2005, Available at http://www.gso.gov.vn (accessed 3 January 2009).

General Statistics Office of Vietnam (2008) Establishment census of Vietnam 2007. Available at http://www.gso.gov.vn (accessed 9 February 2010).

Giesecke, J.A. and Tran Hoang Nhi (2010) Modelling value-added tax in the presence of multi-production and differentiated exemptions, Journal of Asian Economics, 21, 156-173.

Harrison, W. J. and R. K. Pearson (1996) Computing Solutions for Large General Equilibrium Models using GEMPACK’, Computational Economics 9, 83-127. Harrison, W. J., J. M. Horridge and R. K. Pearson (2000) Decomposing Simulation Results with Respect to Exogenous Shocks, Computational Economics 15, 227-249.

HM Revenue \& Customs (2004) VAT refunds for travelers departing from the European Community (EC). Notice 704/1 (September 2004). London. Available at http://customs.hmrc.gov.uk (accessed 9 February 2010).

HM Revenue \& Customs (2010) Measuring Tax Gaps 2009. London. Available at http://www.hmrc.gov.uk/stats/measuring-tax-gaps.pdf (accessed 9 February 2010).

Hybka (2009), VAT collection efficiency in Poland before and after accession to the European Union - A comparative analysis, Ekonomica, 85, 7-18.

Jack, W. (1996) The efficiency of VAT implementation: A comparative study of Central and Eastern European countries in transition. IMF working paper, WP/96/79. 
Keen, M. \& Smith, S. (2006) VAT fraud and evasion: what do we know and what can be done?”. National Tax Journal, 59, 861-887.

Matthews, K. (2003) VAT Evasion and VAT Avoidance: Is There a European Laffer Curve for VAT?, International Review of Applied Economics, 17, 105-114. Ministry of Finance (2007) Final accounts of stage budget balance FY 2005. Available at http://www.mof.gov.vn (accessed 10 December 2009).

National Assembly (2003) Law on amendment of the law on Value added tax. Available at http://vbpq.mof.gov.vn/home.aspx (accessed 2 June 2007). Nguyen Van Chinh (2001) Some issues in estimation of some integrated indicators and compilation main Accounts in Vietnam. Country report for concluding workshop on RETA 5874: Rebasing and Linking of National Account Series in Selected Development Member Countries (DMCs) to be held from 13-16 February 2001 in Bangkok, Thailand.

OECD (2008) Consumption tax trends 2008: VAT/GST and excise rates, trends and administration issues, OECD, Paris.

Sandford, C. T. (1989) Administrative and compliance costs of taxation, Fiscal Publications, Bath.

Sandford, C. T. (1995) Tax compliance costs : measurement and policy, Fiscal Publications, Bath.

Schneider, F. (2005) Shadow economies around the world: what do we really know? European Journal of Political Economy, 21, pp. 598-642.

Schneider, F., and Buehn, A. (2007) Shadow economies and corruption all over the World: Revised estimates for 120 countries. Economics: the Open Access, Open Assessment E-Journal, 1, 2007-9. Available at http://www.economicsejournal.org/economics/journalarticles/2007-9 (accessed March 2010). 
Swedish National Tax Agency (2008) Tax gap map for Sweden: How was it created and how can it be used?. Swedish National Tax Agency, Solna.

United Nations (2001) 1993 System of National Accounts, United Nations, Washington, $\quad$ D.C., Available at http://unstats.un.org/unsd/sna1993/introduction.asp (accessed 7 April 2004).

Vietnamese Communist Party (2010) Tourism stimulus program to be launched. Online newspaper, available at http://www.dangcongsan.vn/cpv/ (accessed 8 April 2010). 